\title{
23. PHAEODARIAN RADIOARIA IN SOUTHWEST PACIFIC SEDIMENTS CORED DURING LEG 21 OF THE DEEP SEA DRILLING PROJECT
}

\author{
Paulian Dumitricǎ, Geological Institute, Bucharest, Romania
}

\section{INTRODUCTION}

Althøugh occurrences of phaeodarian remains in a fossil or subfossil state have been recorded long ago by Bailey (1856), Wallich (1869), Borgert (1901), and Cocco (1903), the discovery of most fossil phaeodarians is incontestably an achievement of micropaleontological researches of the last few years. As a consequence of these researches, a series of well-preserved phaeodarian shells have been found in the last decade in Recent and Pleistocene sediments (Riedel, 1963; Reschetnjak, 1969, 1971; Stadum and Ling, 1969; Dumitricǎ, 1972), and in some Middle Miocene deposits (Dumitricǎ, 1964, 1965).

It is indeed true that, due to their chemical nature, phaeodarian skeletons are very or extremely rare in sediments as compared with polycystins or with the phaeodarians in living plankton. However they are much more frequent than was previously believed. Our observations on the cores drilled in Leg 21 and on some samples drilled in Legs 5 and 7 of the DSDP or coming from various Miocene deposits, proved that most of them contain usually rare fragments of phaeodarian skeletons. It is true that they are generally indeterminable and that the chances of finding entire shells are rather small. For this reason, the satisfactions of such finds are so much the greater. In spite of their scarcity, the very few species recorded in sediments of various ages give information, quite fragmentary indeed, about some taxa having constituted some fossil phaeodarian assemblages.

The investigations of the radiolarian-bearing sediments cored in Leg 21 have provided interesting new data concerning the resistance for fossilization of several phaeodarian groups. The described phaeodarian remains have been found associated with polycystine radiolarians, immaterially whether the latter were perfectly preserved in opaline silica or in probably finely crystallized silica. For example, in the Upper Miocene at Site 205 and the Upper Miocene and Pliocene sediments at Site 206 the initially opaline silica of the polycystins appears to be crystallized, the skeletons being of milky white color in air and rather dark in Canada balsam. In spite of this alteration of the structure of the silica, phaeodarian remains are not lacking. On the contrary, it is just within these intervals where the most and best preserved phaeodarians occur. They are practically absent only in the Lower Miocene and Oligocene sediments, where some polycystine tests are partly corroded.

The coring of an almost continuous radiolarian sequence from Oligocene to Quaternary enabled us to follow the occurrence of phaeodarian remains within a long period of time. The result is that the range of some living taxa was thus extended to various levels of the Quaternary, Pliocene, or Miocene. A few species probably extinct or, at any rate still undescribed, were also found at some levels of this sequence.

Generally speaking, almost all suborders and families of Phaeodaria are represented in the cores studied. The range charts of the skeletal remains of phaeodarians show that, besides some species whose occurrence is limited to particular stratigraphic levels, probably because of better possibilities for preservation, there are a few groups the remains of which are resistant enough to occur along the whole sequence. These are especially small shells of Lirella, remains of shells of castanellids, and spines of coelodendrids and Atlanticella.

\section{PHAEODARIANS AT EACH SITE}

In the SW Pacific sediments cored during Leg 21 of the Deep Sea Drilling Project, phaeodarian skeletons have been recorded at the following Sites: 203, 204, 205, and 206.

Site 203

(lat. $22^{\circ} 09.22^{\prime} \mathrm{S}$, long. $177^{\circ} 32.77^{\prime} \mathrm{W}$; water depth $2720 \mathrm{~m}$ )

A rather rich phaeodarian fauna occurs associated with polycystine radiolarians throughout Cores 1 and 2 drilled between 0 and 15 meters below the sea floor. The sediment consists of iron-oxide-rich nannofossil ooze with two intercalations of volcanic glass, and is Upper Pleistocene to Holocene in age.

In the two intercalations of volcanic glass the phaeodarians are practically lacking, not because of their dissolution but because of the dissemination caused by the rapid sedimentation of the volcanic glass. As a matter of fact, within this interval of 15 meters there is no indication of dissolution of the phaeodarian skeletons with depth. On the contrary, the richest fauna occurs approximately at the middle part of the sequence, where the richest assemblage of polycystine radiolarians occurs also at this site. As is shown in Figure 1, the most frequent remains of phaeodarians belong to challengerids (Protocystis, Lithogromia?), lirellids (Lirella, Borgertella), castanellids (Castanidium, etc.), medusettids (Euphysetta), and coelodendrids (indeterminable spines).

\section{Site 204}

(lat. $24^{\circ} 57.27^{\prime} \mathrm{S}$, long. $174^{\circ} 06.69^{\prime} \mathrm{W}$, water depth $5354 \mathrm{~m}$ )

Phaeodarians occur only in the superficial layer of Recent sediment (204-1-1, 0-2 cm). They disappear rapidly with depth in sediment so that at $45 \mathrm{~cm}$ below the surface they are practically absent. In the sample cited above, phaeodarian remains are rare, being represented by the following taxa: Aulographis taumorpha, Aulospathis variabilis, Protocystis harstoni, Lirella marina, L. melo, 


\begin{tabular}{|c|c|c|c|c|c|c|}
\hline \multirow[b]{2}{*}{ Taxa } & \multicolumn{6}{|c|}{ Sample } \\
\hline & 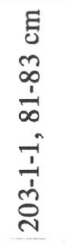 & 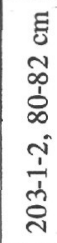 & 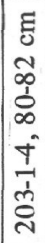 & 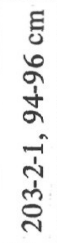 & 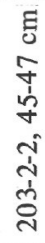 & ڤे \\
\hline Aulographis taumorpha & 2 & & 1 & & & \\
\hline Aulographonium candelabrum & & & & 1 & & \\
\hline Aulographonium pulvinatum & & 1 & & & & \\
\hline Aulographonium cf. indicum & & & & 1 & & \\
\hline Aulocantha ? spp. (spines) & & & & $\mathrm{xx}$ & & \\
\hline Castanidium ? fenestratum & & 15 & 1 & 26 & & \\
\hline Castanidium sp. & & 1 & & & & \\
\hline Castanea? sp. 1 & & 5 & & 2 & & \\
\hline Castanea? sp. 2 & & 1 & & & & \\
\hline Porospathis holostoma & & & & 1 & 1 & 1 \\
\hline Protocystis xiphodon & & & & 1 & & \\
\hline Protocystis harstoni & & & & 1 & 1 & \\
\hline Protocystis cf. thomsoni & & & & 1 & & \\
\hline Lithogramia ? sp. 1 & & 6 & 3 & 24 & 2 & 2 \\
\hline Lithogromia? sp. 2 & & 2 & & 3 & & \\
\hline Lirella marina & $\mathrm{x}$ & $\mathrm{x}$ & & 52 & & \\
\hline Lirella melo & & & & 3 & & \\
\hline Borgertella caudata & & & & 14 & & \\
\hline Medusetta inflata & 1 & & & & & \\
\hline Euphysetta elegans & 1 & 3 & 3 & 14 & 4 & 2 \\
\hline Euphysetta lucanii & & & & 2 & & \\
\hline Euphysetta pusilla & & & & 1 & & \\
\hline Euphysetta cf. nathorstii & & & & 2 & & \\
\hline Coelodendrids gen. et sp. ind. & $\mathrm{x}$ & $\mathrm{x}$ & $\mathrm{x}$ & 23 & $\mathrm{x}$ & $\mathrm{x}$ \\
\hline
\end{tabular}

Figure 1. Distribution of Phaeodaria at Site 203.

Euphysetta elegans, and Atlanticella sp. 1, and in addition fragments of shells of castanellids and a few thorny spines.

Site 205

(lat. $25^{\circ} 30.99^{\prime} \mathrm{S}$, long. $177^{\circ} 53.95^{\prime} \mathrm{E}$; water depth $4320 \mathrm{~m}$ )

At this site the occurrence of the phaeodarians is restricted to Cores 5 to 7 of Upper Miocene age. The occurrence of polycystine radiolarians is also restricted to these cores. The complete list of the skeletal remains of phaeodarians encountered in these cores is given in Figure 2. The following facts are worth noting-within this interval were found single shells of Borgertella erectostoma n. sp. and Medusetta ? costata n. sp., the oldest well preserved castanellids, and the oldest remain of Euphysetta.

\section{Site 206}

(lat. $32^{\circ} 00.75^{\prime} \mathrm{S}$, long. $165^{\circ} 27.15^{\prime} \mathrm{E}$; water depth $3196 \mathrm{~m}$ )

Although the phaeodarian remains recorded in the cores at this site are rare and little diversified as compared with the previous sites, they are of considerable value because they could be recorded almost constantly from Quaternary to the base of Middle Miocene. Lirella marina, and fragments of shells of castanellids, and of spines of

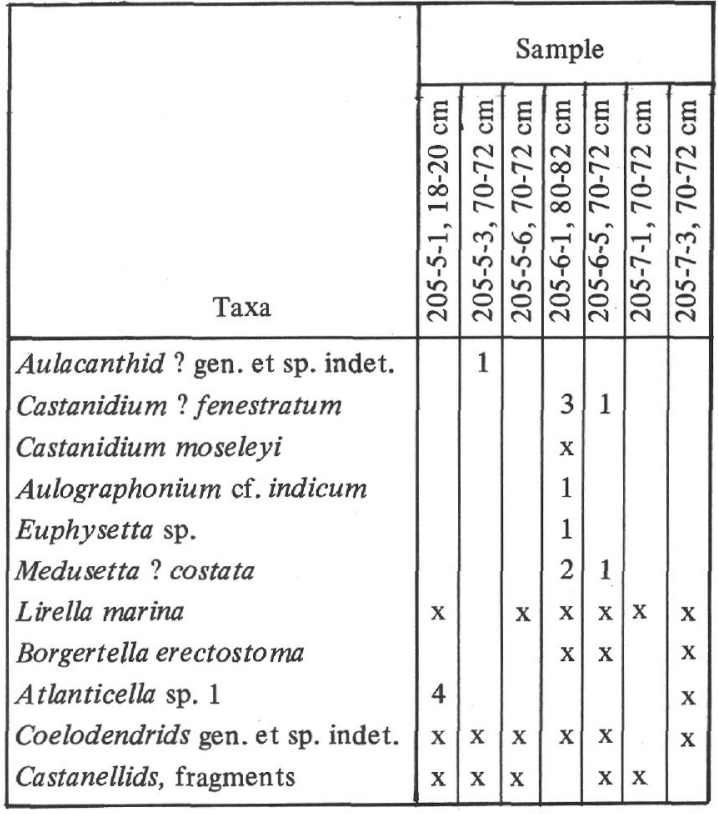

Figure 2. Distribution of Phaeodaria at Site 205.

Atlanticella and coelodendrids are among them. All these remains practically disappear in the sediments older than the Middle Miocene. Their disappearance was probably caused by bottom currents that destroyed the delicate skeletons of phaeodarians, polycystines, dinoflagellates, etc. As a result of such currents the organic remains preserved below Cores 30 to 32 are constituted of fragments of robust sponge spicules, robust polycystine shells, and particularly thick-walled cephalises of various nassellarians. A remarkable member of the phaeodarian assemblage at Site 206, the occurrence of well preserved Concharium binoculatum n. sp., should be mentioned, the only fossil concharid known until present. The distributions of all phaeodarian remains is given in Figure 3.

\section{SYSTEMATICS \\ Subclass RADIOLARIA \\ Order PHAEODARIA \\ Suborder PHAEOCYSTINA \\ Family AULACANTHIDAE}

The radial spines, which are the most distinctive skeletal elements of the members of this family, have been very rarely encountered in sediments. With his Aulographis asteriscus, a spine with twenty conical teeth on an extremity, recorded in the Upper Miocene of Sicily (Italy), Cocco (1903) is the first who mentioned the presence of an aulacanthid species in the fossil state. However, as he did not illustrate this spine, his identification should be regarded circumspectly. Remains certainly belonging to this family have been illustrated recently by Reschetnjak $(1969,1971)$ in bottom sediments from the Antarctic sector of the Pacific Ocean. They are remains of Aulospathis variabilis triodon and Aulographonium mediterraneum. A spine of aulacanthid type was also illustrated recently in the Pleistocene sediments of the Mediterranean Sea (Dumitrica, 1972).

In SW Pacific sediments cored in Leg 21, rare spines of Aulacanthidae have been encountered from Holocene to Upper Miocene. Apart from some undeterminable spines, the following taxa could be determined: Aulographis taumorpha, Aulographonium candelabrum, A. pulvinatum, A. cf. indicum, Aulospathis variabilis, and Aulacantha sp. 


\section{Genus AULOGRAPHIS Haeckel}

Aulographis taumorpha Haeckel

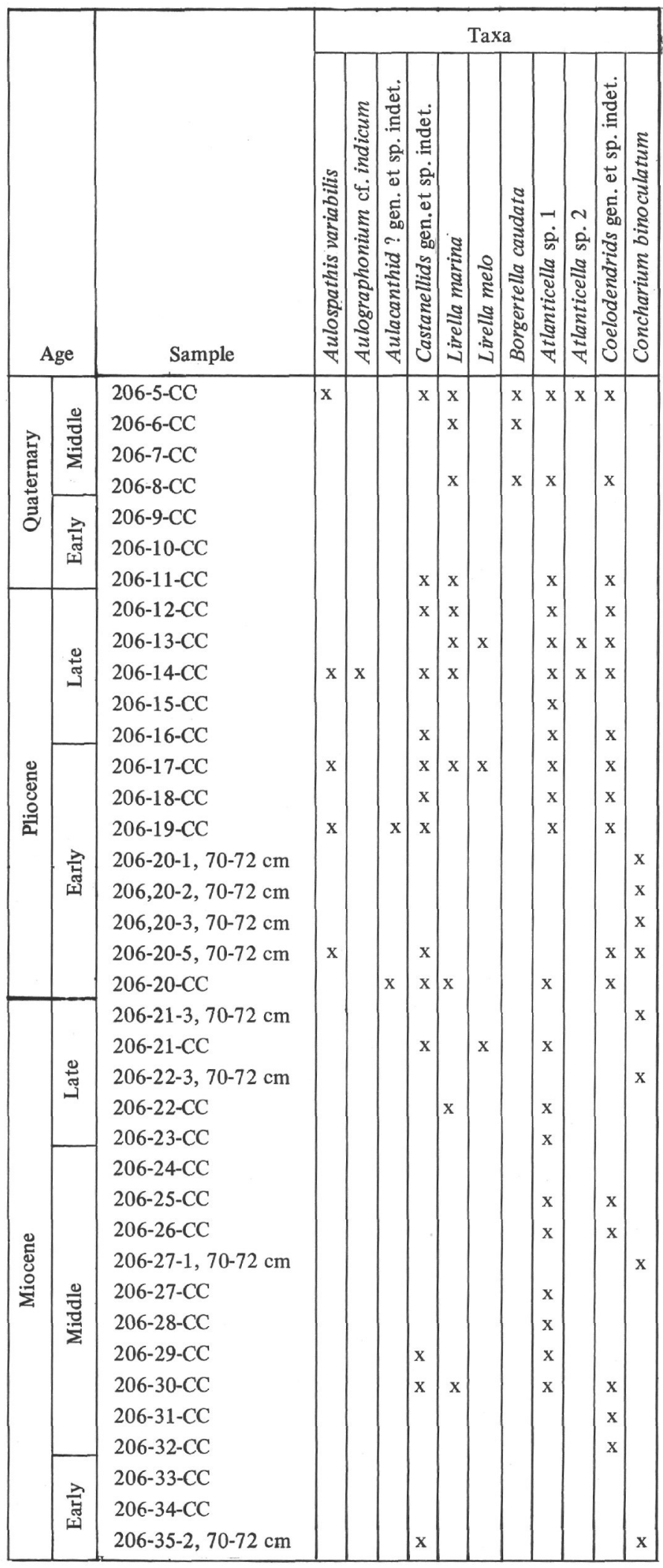

Figure 3. Distribution of Phaeodaria at Site 206.
(Plate 1, Figures 1, 8; Plate 11, Figures 1, 2)

Aulographis taumorpha Haeckel, 1887, p. 1577, pl. 103, fig. 16.

Remarks: Three radial spines of this species characterized by two recurved opposite branches have been encountered in Pleistocene and Recent sediments at Sites 203 and 204.

\section{Genus AULOGRAPHONIUM Haeckel}

Aulographonium candelabrum Haeckel

(Plate 1, Figure 2; Plate 11, Figure 3)

Aulographis (Aulographonium) candelabrum Haeckel, 1887, p. 1583 , pl. 103, fig. 1.

Aulographonium candelabrum Haecker, 1908, p. 69, pl. 6, fig. 56; Reschetnjak, 1966, p. 115, fig. 40 D.

Remarks: A single fairly well preserved distal extremity of a radial spine was encountered in Sample 203-2-1, 94-96 cm. It bears a corona of eight terminal spines.

\section{Aulographonium pulvinatum Haeckel \\ (Plate 1, Figure 9; Plate 11, Figure 8)}

Aulographis (Aulographonium) pulvinata Haeckel, 1887, p. 1582, pl. 103, fig. 26.

Aulocoryne pulvinata Immermann, 1904, p. 60, pl. 6, fig. 9

Aulographonium pulvinatum Haecker, 1908, p. 71, pl. 6, figs. 50,

51.

Remarks: A single specimen quite conformable to the original description and illustration was found in Sample 203-1-2, 80-82 cm.

Aulographonium cf. indicum Haecker

(Plate 1, Figures 4, 5; Plate 11, Figures 5, 9)

? Aulographonium indicum Haecker, 1908, p. 70, pl. 6, fig. 58; Reschetnjak, 1966, p. 116, fig. 40 B.

Remarks: This species, characterized by 9 to 10 terminal branches, appears to be most appropriate for the illustrated fragmentary specimens, one coming from Pleistocene (203-2-1, $94-96 \mathrm{~cm})$, the other from Late Miocene $(205-6-1,80-82 \mathrm{~cm})$ sediments. Number of the thorny terminal branches is 11 in the first specimen, 8 in the second. A third, very poorly preserved spine also bearing 8 terminal branches was found at 206-14, CC (Late Pliocene).

\section{Genus AULOSPATHIS Haeckel \\ Aulospathis variabilis Haeckel (Plate 2, Figures 1, 5)}

Aulospathis bifurca Haeckel, 1887, p. 1586, pl. 104, figs. 1-5. Aulospathis trifurca Haeckel, 1887, p. 1586, pl. 104, figs. 6, 7.

Aulospathis variabilis Haeckel, 1887 , p. 1588 , pl. 104, figs. 14-17; Haecker, 1908, p. 86, pl. 6, figs. 63-67; pl. 7, figs. 72-75.

Remarks: The distal parts of the radial spines, with a more or less inflated terminal knob and two or three terminal branches, were the only remains of this species encountered in SW Pacific sediments. Some tubes have a simple wall (Plate 2, Figure 1). In other tubes the wall is constituted of several concentric layers (Plate 2, Figure 5). The innermost layer is thin and separated by a wide space from the external ones. In the illustrated specimen in the latter figure may be distinguished an inner and an outer darker layer with simple structure, and a median lighter one, with transverse structure. All these layers probably represent growth stages.

-The species was sparsely recorded from Holocene to Early Pliocene.

\section{Genus AULACANTHA Haeckel}

Aulacantha? sp.

(Plate 1, Figures 3, 7; Plate 2, Figure 6)

Remarks: The illustrated spines, and many others of the same type assigned to this genus, are straight or curved and armed with small thorns, the points of which are directed to the distal end. The distal extremity of the spines is simply acute or bears a corona of 3 to 4 teeth. Such spines are common in Aulacantha but many radial tubes of aulosphaerids are of the same type. 
More than twenty spines were found in the Pleistocene in Sample 203-2-1, 94-96 cm and one in Middle Miocene sediments in Sample 206-29, CC.

Aulacanthid ? gen. et sp. indet.

(Plate 2, Figures 2-4; Plate 11, Figure 6)

Remarks: Several curved branching spines, as those illustrated in these figures, were found in Late Miocene at Site 205 and Early Pliocene at Site 206. Their constant and particular morphology indicates that they might belong to the same species. Their generic assignment is difficult to establish. By their morphology these spines appear to be distal parts of radial tubes of aulacanthids. More or less similar forms have been illustrated in Aulospathis pinus (Haecker, 1908, pl. 6, fig. 68) and Aulodendron verticillatum (Reschetnjak, 1966 , p. 43, fig. 17 A).

The wall of these fossil spines is thick and seems to be constituted of many thin concentric layers (6-10) that might represent growth stages.

\section{Suborder PHAEOSPHAERIA}

Family AULOSPHAERIDAE

Not yet recorded in the fossil state.

\section{Family SAGOSPHAERIDAE}

Remarks: Reschetnjak (1971) illustrated a piece of net which came from the bottom sediments of the South Pacific Ocean and was considered to belong to this family. This is the only possible recorded fossil occurrence of sagosphaerids. The verticillate spine illustrated in Plate 11, Figure 10 and the thorny spines illustrated in Plate 3, Figure 6 might be skeletal fragments of sagosphaerids or aulosphaerids, but they might possibly belong to other families.

\section{Suborder PHAEOCALPIA \\ Family CASTANELLIDAE}

Remarks: A remarkably well preserved specimen illustrated by Riedel (1963) from a Quaternary Pacific sediment is the only record of a fossil castenellid known in the literature. The preservation in sediments of the hollow skeletons of members of this family is favored by their chemical composition. As proved by Schmidt (1908, in Reschetnjak, 1966), the skeleton of the Castanellidae is constituted of pure silica. It is to be supposed, however, that there is also a small amount of organic mixture in their skeletons, because the castellids are not preserved in all the radiolarian-bearing sediments and are not always in a good state.

In the cores of Leg 21 rather well preserved shells of castanellids were found in the Quaternary at Site 203 and Late Miocene at Site 205. Fragments of shells were recorded in many other cores at Sites $203,204,205$, and 206. At the last site, such indeterminable fragments occur throughout the Pleistocene-Early Miocene sequence. Generally, the size of these fragments decreases with increasing age of the sediments. The Quaternary specimens are very well preserved. In the Upper Miocene at Site 205 the radial spines of the shells are dissolved, their place being marked on the shell by small circular pores (Plate 3, Figures 7, 8; Plate 4, Figure 4 and especially Figure 3).

\section{Genus CASTANIDIUM Haeckel}

Remarks: Most shells of castanellids found in the sediments cored in Leg 21 belong to this genus. Castanidium moseleyi, $C$. fenestratum, and Castanidium sp. are the only species recorded.

\section{Castanidium moseleyi Haeckel \\ (Plate 4, Figure 3)}

Castanidium moseleyi Haeckel, 1887, p. 1686, pl. 113, fig. 2; Haecker, 1908, p. 166, pl. 37, fig. 281; pl. 38, fig. 288; pl. 39, figs. 293, 294; Kling, 1966, pl. 6, fig. g-1.

Remarks: Several fragments of this distinctive species were found in Sample 205-6-1, 80-82 cm. No fragment with pylome was observed, so that the generic and specific assignment is based on the similarity between these fragments with polyhedral shape and smooth main spines and $C$. moseleyi. Pores are circular or oval. By-spines are small and thin and disposed at each corner of the intervening bars. In the fragments available almost all are broken or dissolved; in their place remain small circular holes.
Castanidium ? fenestratum Haecker

(Plate 3, Figures 7, 8; Plate 4, Figures 4, 6-8, 10, 11; Plate 5, Figures 3, 5)

Castanidium variabile fenestratum Haecker, 1908, p. 163, pl. 37, fig. 282.

Castanidium ? fenestratum Kling 1966, pl. 6, figs. a-f.

Remarks: Most castanellid shells found in some Quaternary and Upper Miocene cores of this leg belong to this species. They have a small, spherical, or slightly oval shell with thin wall. Thickness of the wall decreases from the oral end to the aboral one. Pores are small, unequal, circular, or subcircular, with thin intervening bars. Spines are slender, short, and originate at some of the corners of the bars. The pylome is large, surrounded by a variable number of spines (3-7).

Dimensions: Diameter of shell $220-250 \mu$, of pylome $42-60 \mu$. These dimensions are based on 25 specimens coming from the Pleistocene at Site 203. The Upper Miocene specimens at Site 205 are a little larger. Their measurements, based on four specimens, have the following values: diameter of shell $260-308 \mu$, diameter of pylome $54-85 \mu$.

Although smaller, the specimens herein described are similar to Castanidium? fenestratum as illustrated and described by Kling.

\section{Castanidium $\mathrm{sp}$. \\ (Plate 4, Figure 9)}

Remarks: It is distinguished from $C$. fenestratum by a larger shell and wider pylome and pores. Only one specimen was found in Sample 203-1-2, 80-82 cm. Its dimensions are: diameter of shell $348 \mu$, of pylome $85 \mu$.

\section{Genus CASTANEA Haecke}

Castanea ? sp. 1

(Plate 4, Figures 1, 2, 5; Plate 5, Figure 4)

Remarks: Shell small, with equal small pores separated by wide intervening bars. By-spines small, disposed at some corners of the intervening bars. Pylome narrow, and simple or with two small teeth.

Diameter of shell $260-360 \mu$, of pylome $25-37 \mu$. The dimensions are based on five specimens found in the Quaternary at Site 203.

Castanea ? sp. 2

(Plate 3, Figures 3, 4)

Remarks: Pylome narrow, similar to Castanea ? sp. 1. Shell large, with small pores and short by-spines. One specimen found in Sample 203-1-2, 80-82 cm. Diameter of shell $490 \mu$, of pylome $30 \mu$.

\section{Family POROSPATHIDAE}

Genus POROSPATHIS Haeckel

Porospathis holostoma (Cleve)

(Plate 5, Figures 1, 2,6)

Porospathis holostoma (Cleve), Haecker, 1908, p. 240, pl. 48, figs. 371-376; pl. 49, figs. 392, 393; Borgert, 1910, p. 387, pl. 29, figs. 1-8; pl. 30, figs. 1, 2; Schröder, 1913, p. 166, text-fig. 9; Reschetnjak, 1966, p. 166, fig. 52; Stadum and Ling, 1969, p. 485, pl. 1, figs.16-18.

Porospathis sp. aff. P. holostoma Dumitricà, 1972, p. 842, pl. 15, fig. 14.

Remarks: This species is commonly found in some sediments. Stadum and Ling have remarked that it is the most abundant phaeodarian encountered in the sediments of the Norwegian Sea.

In the SW Pacific they were very rare: three almost complete specimens were observed in Core 2 at Site 203. They have a short cylindrical peristome similar to that illustrated by Reschetnjak (1966), and appearing to correspond to the thick-walled tube to which the long trumpet-like peristome is attached (Borgert, 1910, Schröder, 1913). Other occurrences of this species in the Quaternary cores drilled in this leg refer to fragments of shell with triangular structure.

Older occurrences were not recorded in the samples of this leg. Porospathis may be, however, preserved in pre-Quaternary sediments. Polypetta mamillata, mentioned by Cocco (1903) in the Upper Miocene of Sicily (Italy), is such an occurrence. The oldest 
sediments containing fragments of shells of Porospathis are the so-called Radiolarian Schist Horizon of Middle Miocene age (Cannartus laticonus Zone) from the Rumanian Subcarpathians.

\section{Suborder PHAEOGROMIA \\ Family CHALLENGERIIDAE}

Remarks: The challengeriids are incontestably the most frequent phaeodarians in sediments, if not numerically, at least specifically. About twenty species belonging to Lithogromia, Protocystis, and Challengeron are known at present in the fossil state. Most of them have been recorded in the Quaternary. No Pliocene or Upper Miocene occurrences are known. The oldest occurrence of challengeriids is of Middle Miocene age (Cannartus laticonus Zone) and refers to several species belonging to the three genera listed above described by Dumitricà $(1964,1965)$.

In Leg 21, shells of challengeriids have been frequently encountered only in the Quaternary at Sites 203 and 204.

\section{Genus PROTOCYSTIS Wallich \\ Protocystis xiphodon (Haeckel) \\ (Plate 9, Figure 2)}

Challengeria xiphodon Haeckel, 1887, p. 1648; Haecker, 1908, p. 260 , pl. 49 , figs. $378-381$.

Protocystis xiphodon Stadum and Ling, 1969, p. 483, pl. 1, figs. 4, 5.

Remarks: A single broken specimen was found at Site 203.

Protocystis harstonii (Murray)

(Plate 8, Figure 5)

Challengeria harstoni Murray, 1876, pl. A, fig. 14.

Protocystis harstoni Haecker, 1908, p1. 50, figs. 396-398; Stadum and Ling, 1969 , p. 483, pl. 1, figs. 1-3.

Remarks: Very rare. Only three specimens have been encountered in Quaternary sediments at Sites 203 and 204. Length of shell 90-108 $\mu$, width $83-100 \mu$.

\section{Protocystis cf. thomsoni (Murray) \\ (Plate 7, Figure 6)}

Protocystis thomsoni (Murray), Ling, 1966, p. 203-214, pl. 1, figs. $1-11 ;$ pl. 2, figs. $1-7$.

Remarks: One broken specimen found at Site 203 in Quaternary sediments.

\section{Genus LITHOGROMIA Haeckel}

Remarks: In a previous paper (Dumitricà, 1965) it was mentioned that in Protocystis fossilis the peristome showed various degrees of preservation, from forms with well-preserved peristome to forms without peristome. In other words, there was a continuous series from shells of the Protocystis type to shells of the Lithogromia type. We wondered at that time if Lithogromia could not be merely young forms of Protocystis. For our discussion of Lithogromia, however, it does not matter whether this possibility is true or not.

In the first two cores at Site 203 are two types of challengeriids with very well preserved shell but lacking a peristome. In the haeckelian system they are species of Lithogramia. What hampers such as assignment in this case is the fact that the two types of "Lithogromia" are quite similar to Protocystis xiphodon (more than 40 specimens as those illustrated in Plate 7, Figure 5 and Plate 8 , Figures 1-4) and to $P$. thomsoni (Plate 7 , Figures 1,2 ). We would have been inclined to assign them to these species, considering that the peristome was destroyed by fossilization. However, it seems that this is not the case with these specimens, because in the same sample there were found a poorly preserved specimen of $P$. xiphodon (Plate 9, Figure 2) with well-preserved peristome and a broken shell, and another poorly preserved specimen probably belonging to $P$. thomsoni (Plate 7, Figure 6) having a rather well preserved peristome. In such circumstances it seems that the specimens under discussion lacking a peristome might be ascribed to Lithogromia. For the moment they are listed as Lithogromia ? sp. 1 (?P. xiphodon) and Lithogromia? sp. 2 (?P. thomsoni).
Family LIRELLIDAE

Genus LIRELLA (Ehrenberg) Loeblich and Tappan

Two species, L. marina and $L$. melo, the most common species of this genus, have been recorded in the cores investigated.

Lirella marina (Bailey)

(Plate 6, Figures 6-8; Plate 9, Figure 8; Plate 12, Figures 10-12)

Cadium marinum Bailey, Bütschli, 1882, pl. 32, fig. 15; Haecker,

1908 , p. 281 , pl. 51, fig. 416 ; Reschetnjak, 1966, p. 174 , fig.

106.

Remarks: This species was commonly encountered in the sediments cored at four sites: 203, 204, 205, and 206 of Leg 21. It was almost uninterruptedly recorded not only in the Quaternary, where it had already been found by some previous workers, but also in the Pliocene and Upper Miocene at Site 206.

Two morphological varieties have been recognized: one has a thick wall, an unmodified convex outline, and an ornamentation consisting of 10 to 11 thick longitudinal ridges on half a diameter; the ridges are continuous from the oral end to the aboral (Plate 6, Figures 6, 8; Plate 12, Figure 10). The other variety has a spindle-shaped form, a longer peristome, and many more longitudinal ridges (18-22 on a semicircle) (Plate 6, Figure 7; Plate 9, Figure 8; Plate 12, Figures 11, 12). The ridges seem to disappear to the oral end. It is not clear whether they are simple morphological varieties or two independent taxa. The longitudinal ridges are not smooth; they are constituted of two rows of alternating tubercules (see Plate 6, Figure 6, a scanning electron micrograph taken by J. P. Caulet in the Geological Laboratory of the National Natural History Museum in Paris.

\section{Lirella melo (Cleve)}

(Plate 7, Figures 3, 4; Plate 12, Figure 9)

Cadium melo (Cleve), Jörgensen, 1905, p. 142, pl. 18, fig. 13; Haecker, 1908, p. 282, pl. 51, fig. 415; Schröder, 1913, p. 168, text-fig. 10; Stadum and Ling, 1969, p. 484, pl. 1, figs. 6-8; Reschetnjak, 1971, fig. 11.

Remarks: Presence of this species in Recent and Pleistocene sediments has already been recorded by Reschetnjak $(1969,1972)$, Stadum and Ling (1969), and Dumitrica (1972). In the SW Pacific it was encountered in Quaternary, Pliocene, and Late Miocene sediments. It is much more rare than $L$. marina.

\section{Genus BORGERTELLA new genus}

Type species: Cadium caudatum Wallich.

Diagnosis: Shell constituted of two main parts: an egg-shaped chamber closed at the aboral end and armed with a hollow spine, and a long, more or less curved, trumpet-like peristome. The inner cavities of the two parts are separated by a diaphragm and communicate only through a narrow tube entering the peristomal cavity. If the curvature of the peristome is considered as being ventral, the tube is situated by the right wall of the shell (Plate 12, Figure 15) and is directed dorsally. Surface smooth or with longitudinal ridges.

Remarks: Borgertella is proposed for Cadium caudatum Wallich, C. inauris Borgert, and the new species, Borgertella erectostoma. It differs from Lirella in having the diaphragm mentioned. Apparently previous authors did not observe this peculiar inner tube which is clearly visible in almost all species observed both in Quaternary and in Upper Miocene sediments.

\section{Borgertella caudata (Wallich)}

(Plate 8, Figures 6-8; Plate 12, Figures 13-17)

Cadium caudatum Wallich, Bütschli, 1882, pl. 32, fig. 15a.

Cadium inauris Borgert, 1910, p. 402, pl. 30, figs. 4-10.

Remarks: Most specimens fit the description given by Borgert for $C$. inauris, except for the arch connecting the oral spine with the aboral one. It is broken in the fossil material, the spines being preserved only by their proximal parts. In the specimens resembling B. caudata no oral spine was observed. As, except for the oral spine, the shells of the two species are quite similar, they appear to be synonymous. Borgert (1910) himself recognized that they are difficult to separate. Borgert's description should be completed with description of the diaphragm separating the shell cavity from the peristomal one. The diaphragm is generally perpendicular or slightly 
oblique to the axis of the shell chamber. The diaphragmatic tube is short and directed slightly dorsally.

D. caudata was found in the Quaternary sediments at Sites 203 and 206.

Borgertella erectostoma new species

(Plate 8, Figures 9, 10; Plate 12, Figures 18-21)

Description: The first segment oval with the ventral side much more inflated than the dorsal. The aboral spine long and curved ventrally. The diaphragm between the two cavities is oblique to the axis of the shell, so that the ventral part of the first segment is much longer than the dorsal. In the ventral part the diaphragm is located at the constriction between the shell and peristome. The diaphragmatic tube is long, dorsally directed, and located near the right side of the shell. The peristome is generally straight and deviates from the longitudinal axis at an angle of about 40 to $45^{\circ}$. The rim of the peristome is expanded as a trumpet. No oral spine. Surface of whole shell covered with numerous longitudinal ridges.

Dimensions: Length of shell without aboral spine 47-52 $\mu$, diameter $19-21 \mu$.

Remarks: Ten specimens have been observed in the Upper Miocene samples 205-6-1, 80-82 cm; 205-6-5, 70-72 cm; and 205-7-3, 70-72 cm.

$B$. erectostoma differs from $B$. caudata in its straight peristome and longer diaphragmatic tube. Because of its stratigraphic position it can be considered as the ancestor of the latter.

\section{Family MEDUSETTIDAE}

Remarks: The shells of some medusettids, particularly of Euphysetta, are well preserved in sediments. Riedel (1963) illustrated the first medusettid in a Quaternary Pacific sediment. Recently, Reschetnjak (1969, 1971) and Stadum and Ling (1969) have recorded three species: Euphysetta elegans, E. amphicodon, and $E$. nathorstii.

In SW Pacific sediments, shells, or fragments of shell and spines of Medusetta, Euphysetta, Atlanticella, and probably Planktonetta have been recorded in Quaternary, Pliocene, and Miocene.

\section{Genus MEDUSETTA Haeckel \\ Medusetta inflata Borgert \\ (Plate 13, Figure 1)}

Medusetta inflata Borgert, 1906, p. 146, pl. 11, figs. 10, 11; Haecker, 1908, p. 305, pl. 53, fig. 437.

Remarks: A single broken specimen with the oral pole moderately well preserved was found in Sample $203-1-1,81-83 \mathrm{~cm}$.

Medusetta ? costata n. sp.

(Plate 5, Figures 7, 9, 10; Plate 13, Figures 2, 3)

Description: Ovoid shell with the aboral end acute and prolonged into a long spine. The oral end is almost always damaged. One specimen, however, preserves an incomplete oral spine. The number of such spines is not known but, judging by the remains preserved in the specimen mentioned, it seems that there are no more than four oral spines, which would correspond to Euphysetta or Medusetta. What is most characteristic of this species is the structure and ornamentation of the shell wall. The surface of the shell is covered on the oral half with 25 to 30 slender longitudinal ridges. The wall is clearly bilamellar (see Plate 5, Figure 10) and perforated by minute pores quincuncially arranged in transverse rows, about 8 to 10 pores in the distance between two ridges. $60 \mu$.

Dimensions: Length of shell without aboral spine $90 \mu$, diameter

Remarks: Only three specimens have been found in the Upper Miocene in Samples 205-6-1, 80-82 cm and 205-6-5, 70-72 cm. In spite of the small number of specimens and their poor preservation, the species is erected because of its structural characteristics, which make it very easily recognizable, and of its age. Apart from Euphysetta sp. it is the oldest medusettid known at present.

\section{Genus EUPHYSETTA Haeckel}

\section{Euphysetta elegans Borgert}

(Plate 5, Figure 8; Plate 6, Figures 1-3; Plate 12, Figure 8)

Euphysetta elegans Borgert, 1906, p. 154, pl. 11, figs. 7-9; Haecker, 1908 , p. 307 , pl. 53 , figs. 435,438 .

Remarks: Shell quite conformable to Borgert's description and illustration. E. elegans is the most frequent species of this genus in the cores studied, particularly at Site 203, where about 30 specimens have been counted. Its occurrence is limited to the Quaternary.

\section{Euphysetta sp. \\ (Plate 6, Figures 4, 5)}

Remarks: A single broken specimen was found in the Upper Miocene Sample 205-6-1, 80-82 cm. Its shape and superficial ornamentation is similar to that of E. elegans, E. amphicodon, and E. staurodon.

\section{Euphysetta lucani Borgert \\ (Plate 9, Figure 1; Plate 12, Figure 6)}

Euphysetta lucani Borgert, Haecker, 1908, p. 306, pl. 53, figs. 436, 439,442 .

Remarks: Two complete specimens have been found in the Pleistocene Sample 203-2-1, 94-96 cm.

\section{Euphysetta pusilla Cleve}

(Plate 9, Figure 6; Plate 12, Figure 5)

Euphysetta pusilla Cleve, 1900, p. 7, pl. 3, fig. 16.

Remarks: One specimen of this extremely rare species was found in the small fraction of Sample $203-2-1,94-96 \mathrm{~cm}$. It is fairly similar to the specimen illustrated and described by Cleve from the North Atlantic. The superficial ornamentation consists of numerous longitudinal lines, which seem to disappear toward the aboral end. The very small alveoli quincuncially disposed in the spaces between lines, mentioned by Cleve, were not observed in this specimen.

Dimensions: Length of shell without spines $62 \mu$, diameter $42 \mu$.

Euphysetta cf. nathorstii Cleve

(Plate 9, Figure 7; Plate 12, Figure 7)

Euphysetta nathorstii Cleve, Stadum and Ling, 1969, p. 485, pl. 1, fig. 5 .

Remarks: In spite of the lack of the oral spines, which are broken off, there is little doubt as to the specific name of this form. The long aboral spine, the fine superficial ornamentation, and the similar size are arguments in favor of this assignment. Two specimens have been recorded in the small fraction of Sample 203-2-1, 94-96 cm.

Dimensions: Length of shell without spines $63 \mu$, diameter $42 \mu$.

\section{Genus ATLANTICELLA Borgert}

Remarks: The primary skeleton of Atlanticella, reduced to a peristome with long chambered spines, is constituted of silica with or without traces of organic substance (Borgert, 1905, p. 119). This explains their preservation in sediments.

At Sites 205 and 206 the remains of Atlanticella are some of the most resistant phaeodarians. They consist of fragments of radial spines and may be very easily recognized by their peculiar structure. Almost all the fragments recorded are straight and probably elliptical in cross section, because they are lying in slides on the same side-that which displays the alternate disposition of the comma-shaped chambers. Such a disposition, characteristic to Atlanticella, is quite similar to that of the grains in an ear of corn. Chambers are evidently open at the acute end, which is always directed to the distal extremity of the spines. The inner wall separating the chambers forms a zigzag line whose amplitude and frequency vary with spines. Most frequently the spines are where the corners of the zigzag are closer to the longitudinal axis than to the right and left sides. Also, most fragments come from the median parts of the spines (Plate 9, Figures 3-5; Plate 10, Figures 2-5; Plate 13 , Figures 7,9 ), very few from the distal ends (Plate 10, Figure 1). This type of spine was considered as Atlanticella sp. 1. It was recorded almost uninterruptedly from Quaternary to Middle Miocene at Site 206, and also in the Upper Miocene at Site 205, and Holocene at Site 204. 
The second type, determined as Atlanticella sp. 2 (Plate 10 , Figures 6, 8; Plate 13, Figures 4-6), is distinguished from the former by its curved shape. The chambers are also alternately open, but on one side and on another of the plane of curvature, and generally more or less toward the convex side. These spines are less frequent at Site 206.

It is not possible at present to establish whether the two types of spines come from several species, from two species, or from the different kinds of spines of one species. The difficulty is due to the absence in the literature of a description of the spine structures in each species.

\section{Genus PLANKTONETTA Borgert}

Planktonetta ? sp.

(Plate 10, Figure 7; Plate 13, Figure 8; Plate 6, Figure 9)

Remarks: The illustrated spine is the only spine of this type found in the samples investigated. It comes from the Pleistocene Sample 203-2-1, 94-96 cm, and belongs probably to Planktonetta or some other large medusettid. At any rate, it is comparable to some spines of Planktonetta atlantica illustrated by Haecker (1908, fig. 33).

The peristomal fragment illustrated in Plate 6, Figure 9 might also belong to this genus or to a species of large medusettids.

\section{Suborder PHAEOCONCHIA Family CONCHARIDAE \\ Genus CONCHARIUM Haeckel \\ Concharium binoculatum n. sp. (Plate 13, Figures 10-13)}

Description: Shell strongly flattened, with elliptical ou tline, and consisting of two unequal valves with a thick, alveolar wall at the periphery and a thin, simply perforated one in the central field. The latter is small in the smaller (dorsal) valve (Plate 13, Figure 11) and much broader in the larger (ventral) one. The inner borders are much broader at the anterior and posterior poles, forming two broad horizontal shelves (Plate 13, Figure 13). They limit the inner cavity of the shell, which initially must have been discoidal, but in most fossil specimens it is altered (Plate 13, Figure 12). In all specimens the inner cavity is lined with a thick, transparent, structureless layer of brown color, the chemical nature of which seems to be chitinous. Of a similar nature is probably the dark brown ligament of some living species, in connection with which Haeckel (1887) wrote that it "is not dissolved by mineral acids, unless long applied."

The two valves lack teeth but are solidly connected so that they are generally found together. The junction of the valves appears to be effected in a double way: at the anterior and posterior poles the valves in many specimens are in tight contact on the whole surface of the two shelves, whereas in the middle part, the lateral margins of the valves fit one into another. This kind of junction is wholly comparable to that of many toothless ostracods.

A remarkable peculiarity of the species is the double structurealveolar and simply porous-of its shell wall. The alveoli are generally disposed perpendicular to the inner or outer surface of the valves and are very well developed at the anterior and posterior poles. From the inner margin of the shelves toward the central field their length decreases, faster in the larger valve and slower in the smaller one. The structure of the alveoli in this species is unknown among concharids. The alveoli are closed at their inner and outer ends. However, their cavities are not entirely closed, because in each lateral wall of the alveoli there is one, seldom two pores (Plate 13, Figure 10). In this way the cavity of an alveola communicates directly with the cavities of the adjoining alveoli.

The pores of the central field are circular, small, and arranged in frequently disturbed rows. They decrease in diameter and are fainter around the center of the valves. The latter is mostly surrounded by several concentric elliptical rings. The concentric structure appears to belong to the chitinous layer and not to the porous field.

By its behavior in Canada balsam the skeleton of $C$. binoculatum does not seem to be siliceous or at least not entirely siliceous. It is of light brown color and rather faint, particularly the alveoli, if not filled with air. Its behavior in such a medium is thus wholly comparable to that of the theca or dinoflagellates.

Material: Sixteen well preserved specimens, including separate valves and double-valved shells.

Dimensions: Length of shell $370-400 \mu$, width $180-230 \mu$.

Remarks: This species is the only fossil species of concharids known until now. It was found from Lower Pliocene to the upper part of the Lower Miocene at Site 206 (Cores 20, 21, 22, 27, and 35).

\section{Suborder PHAEODENDRIA \\ Family COELODENDRIDAE}

Coelodendrids, gen. et sp. indet.

(Plate 2, Figures 7-10; Plate 3, Figures 1, 2;

Plate 11, Figures 4, 7; Plate 12, Figures 1,2,4)

Remarks: The remains of coelodendrids are among the most frequent and most constant phaeodarians in the sediments cored in Leg 21. Their occurrence is uninterrupted from Quaternary to the base of the Middle Miocene at Site 206 and restricted to the radiolarian sequences at Sites 203, 204, and 205.

The most frequent remains are distal ends of radial spines formed of straight or slightly curved siliceous tubes, twice or three times dichotomously ramified, the terminal branches of which bear a spathilla with small recurved teeth. Each new ramification is situated in a plane perpendicular to the previous ramification.

Such types of spines are common among the members of this family, especially in genera Coelodendron, Coelacanthum, etc. Most fragments are from distal parts of radial spines. Very few are proximal fragments (Plate 3, Figure 2; Plate 12, Figures 1, 2).

\section{REFERENCES}

Borgert, A., 1905. Die Tripyleen Radiolarien der Plankton-Expedition. Atlanticellidae. Erg. Plankt.-Exp. Humboldt-Stiftung. 3(3), 115.

1906. Die Tripyleen Radiolarien der PlanktonExpedition. Medusettidae. Erg. Plankt.-Exp. HumboldtStiftung. 3(4), 131.

1910. Die Tripyleen Radiolarien der PlanktonExpedition. Porospathidae und Cadiidae. Erg. Plankt.Exp. Humboldt-Stiftung. 3(10), 381.

Bütschli, O., 1882. Radiolaria. In Klassen und Ordnungen des Thier-Reichs. Bronn H. G., Ed. 1(1), 322.

Cleve, P. T., 1900. Notes on some Atlantic planktonorganisms. Handl. Kgl. Svenska Vetensk.-Akad. 34(1), 1.

Cocco, L., 1903. I. Radiolari fossili del tripoli di Condro (Sicilia). Rend. R. Acad. Sci. Lett. Arti Acireale, Cl. Sci. Ser. 3. 3(2), 1.

Dumitricǎ, P., 1964. Asupra prezentei unor radiolari din familia Challengeridae (ord. Phaeodaria) in Tortonianul din Subcarpati. Stud. si Cerc. Geol., Geof., Geogr. Ser. Geol. 9(1), 217.

1965. Sur la présence de Phéodaires fossiles dans le Tortonien des Subcarpathes roumaines. C. R. Acad. Sci. Paris. 260(1), 250.

1972. Cretaceous and Quaternary Radiolaria in deep sea sediments from the northwest Atlantic Ocean and Mediterranean Sea. In Ryan, W. B. F., Hsü, K. J. et al., 1972. Initial Reports of the Deep Sea Drilling Project, Volume XIII. Washington (U.S. Government Printing Office). 829.

Haeckel, E., 1887. Report on the Radiolaria collected by H.M.S. Challenger during the years 1873-1876. Rept. Voyage Challenger, Zool. 18. 1803 p.

Haecker, V., 1908. Tiefsee Radiolarien. Speziel Teil, L. 1, Aulacanthidae-Concharidae. Deutsch. Tiefsee-Exped., Wiss. Ergebn. 14. 336 p.

Immermann, F., 1904. Die Tripyleen Familie der Aulacanthiden. Erg. Plank.-Exp. Humboldt-Stiftung. 3(1), 1 . 
Kling, S. A., 1966. Castanellid and Circoporid radiolarians: systematics and zoogeography in the eastern North Pacific. Ph. D. dissertation, Univ. Calif., San Diego. $175 \mathrm{p}$.

Ling, H.-Y, 1966. The radiolarian Protocystis thomsoni (Murray) in the northeast Pacific Ocean. Micropaleontology. 12(2), 203.

Loeblich, A. R., Jr, and Tappan, H., 1961. Remarks on the systematics of the Sarkodina (Protozoa), renamed homonyms and new and validated genera. Proc. Biol. Soc. Washington. 4, 213.

Popofsky, V., 1926. Die Tripyleen Radiolarien der Plankton-Expedition. Coelodendridae (einschliesslich Coelographidae Haeckel). Erg. Plank.-Exp. HumboldtStiftung. 3(13), 1.

Reschetnjak, V. V., 1966. Glubokovodnye radiolyarii Phaeodaria severo-zapadnoi chasti Tihogo okeana. In
Fauna S.S.S.R. Radiolyarii. Akad. Nauk S.S.S.R., Zool. Inst. N. Ser. 94, 208 p.

1969. Radiolyarii otryada Phaeodaria v sovremennih donnih osadkah i drevnih otlozheniyah. In Iskopaemye i Sovremennye Radiolyarii. 133.

, 1971. Occurrence of phaeodarian Radiolaria in Recent sediments and Tertiary deposits. In The Micropalaeontology of Oceans. Funnell, B. M., and Riedel, W. R., Eds. Cambridge Univ. Press. 343.

Riedel, W. R., 1963. The preserved record: Paleontology of pelagic sediments. In The Sea. Hill, M. N., Ed. New York (Interscience Publishers) 3, 866.

Schröder, O., 1913. Die Tripyleen Radiolarien (Phaeodarien). Deutsch. Süđpolar-Exped. 1901-1903. 14 (Zool. 6(2), 113.

Stadum, C. J. and Ling, H.-Y, 1969. Tripylean Radiolaria in deep-sea sediments of the Norwegian Sea. Micropaleontology. 15(4), 481 . 



\section{PLATE 1}

Figures 1, 2, 4, 5, 8, 9, $\times 260$; Figure 7, $\times 500$;

Figures 3, 6, X 520

Figures 1,8 Aulographis taumorpha

1: DSDP 203-1-1, 81-83 cm.

8: DSDP 203-1-4, 80-82 cm.

Figure 2 Aulographonium candelabrum, DSDP 203-2-1, 94-96 $\mathrm{cm}$.

Figures 3, 7 Aulacantha? sp. 3: DSDP 206-29, CC.

7: DSDP 203-2-1, $94-96 \mathrm{~cm}$.

Figures 4, $5 \quad$ Aulographonium cf. indicum

4: DSDP 205-6-1, 80-82 cm.

5: DSDP 203-2-1, $94-96 \mathrm{~cm}$.

Figure 6

Aulacanthid ?, gen. et sp. indet., DSDP 205-6-1, $80-82 \mathrm{~cm}$.

Figure 9

Aulographonium pulvinatum, DSDP 203-1-2, 80-82 $\mathrm{cm}$. 


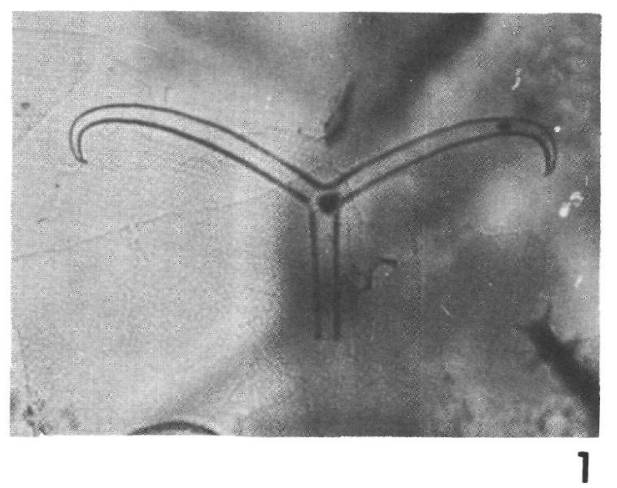

PLATE 1
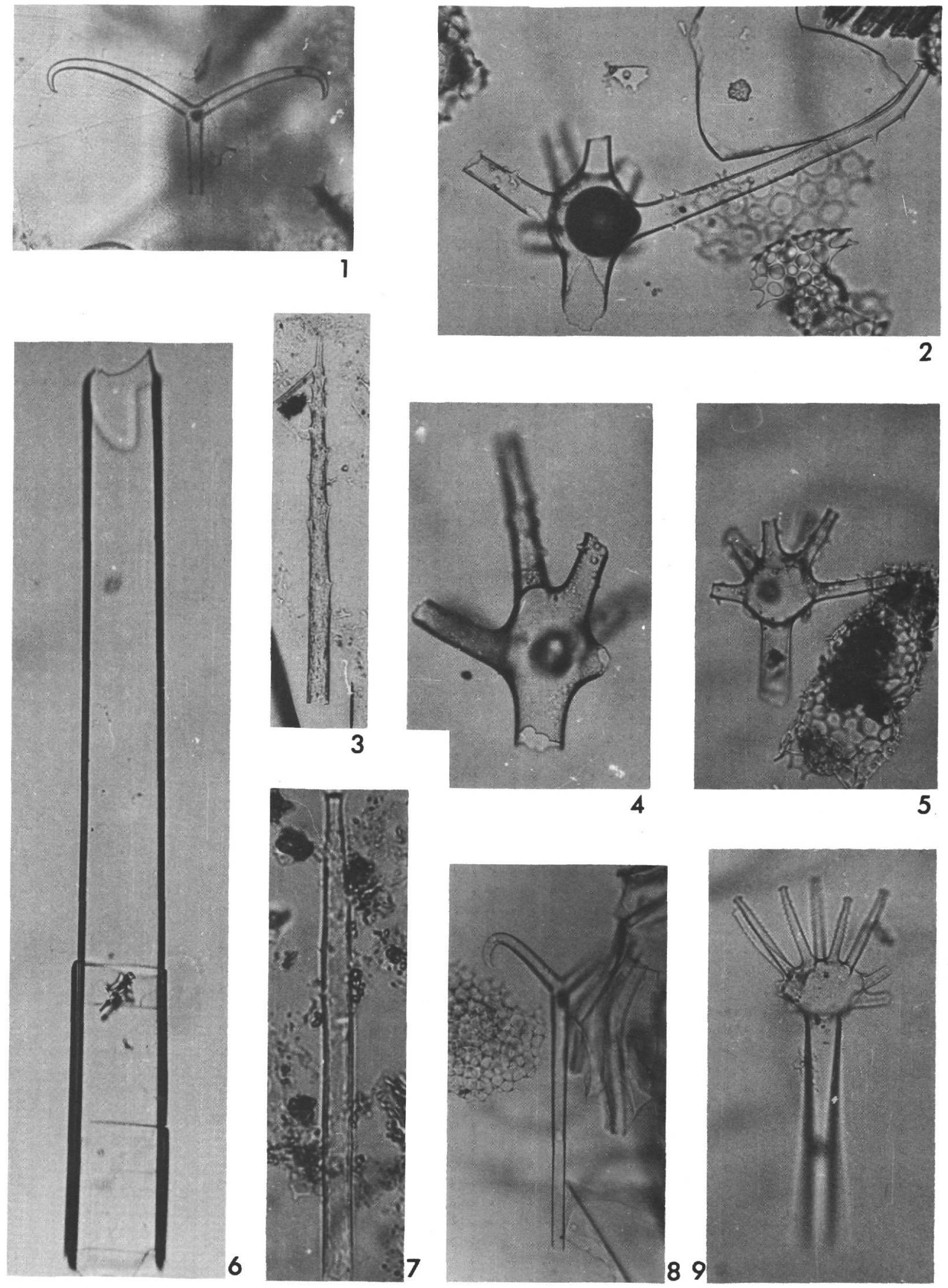


\section{PLATE 2}

Figures 1-5, X260; Figure 6, $\times 520$;

Figures $7-9, \times 300$; Figure $10, \times 150$

Figures 1, 5 Aulospathis variabilis

1: Tube with two terminal branches, DSDP 204-1-1, $0-2 \mathrm{~cm}$.

5: tube with three terminal branches, DSDP 206-14, CC.

Figures 2-4 Aulacanthid ?, gen et sp. indet.

2, 3: the same specimen focused at different levels, DSDP 206-19, CC.

4: DSDP 206-20, CC.

Figure 6

Aulacantha ? sp., DSDP 203-2-1, 94-96 cm.

Figures 7-10 Coelodendrids, gen. et sp. indet.

7, 8, 10: DSDP 203-1-1, 81-83 cm.

9: DSDP 203-1-4, 80-82 cm. 
PHAEODARIAN RADIOLARIA

PLATE 2
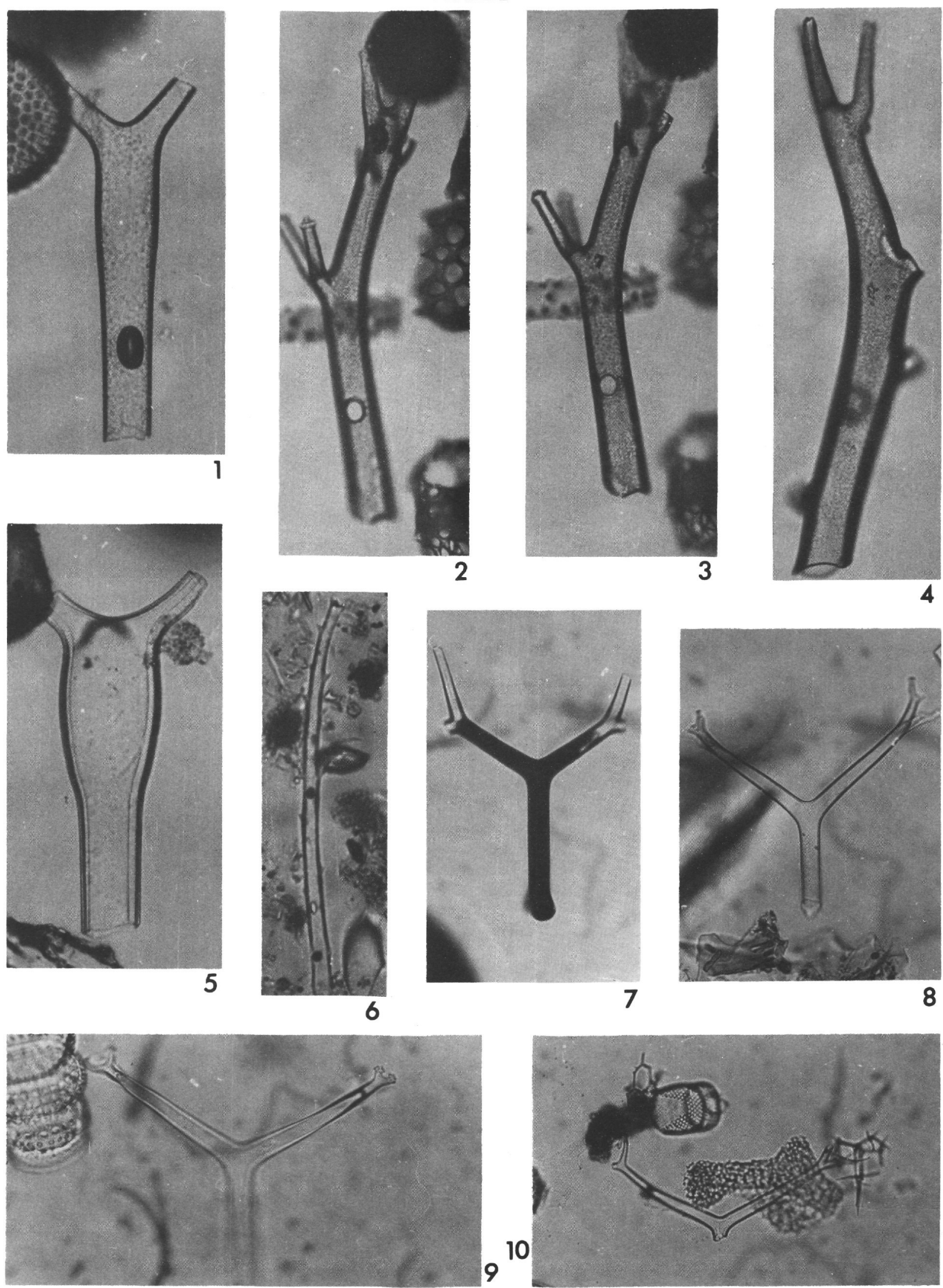


\section{PLATE 3}

Figures 1, 6, X300; Figure 2, $\times 460$;

Figures 3, 4, 7, 8, X160; Figure 5, $\times 260$

Figures 1, 2 Coelodendrids, gen. et sp. indet.

1: distal fragment of radial spine, DSDP 203-1-1, $81-83 \mathrm{~cm}$.

2: proximal fragment of a radial spine, DSDP 206-29, CC.

Figures 3,4 Castanea ? sp. 2, the same specimen focused at diameter and at surface, showing the narrow aperture, DSDP 203-1-2, 80-82 cm.

Figure 5 Phaeodarian, gen. et sp. indet., DSDP 205-6-1, 80-82 $\mathrm{cm}$.

Figure 6 Phaeodarian, gen. et sp. indet., DSDP 203-1-1, 81-83 $\mathrm{cm}$.

Figures 7, 8 Castanidium ? fenestratum

5: 205-6-1, 80-82 cm.

8: DSDP 205-6-5, 70-72 cm. 

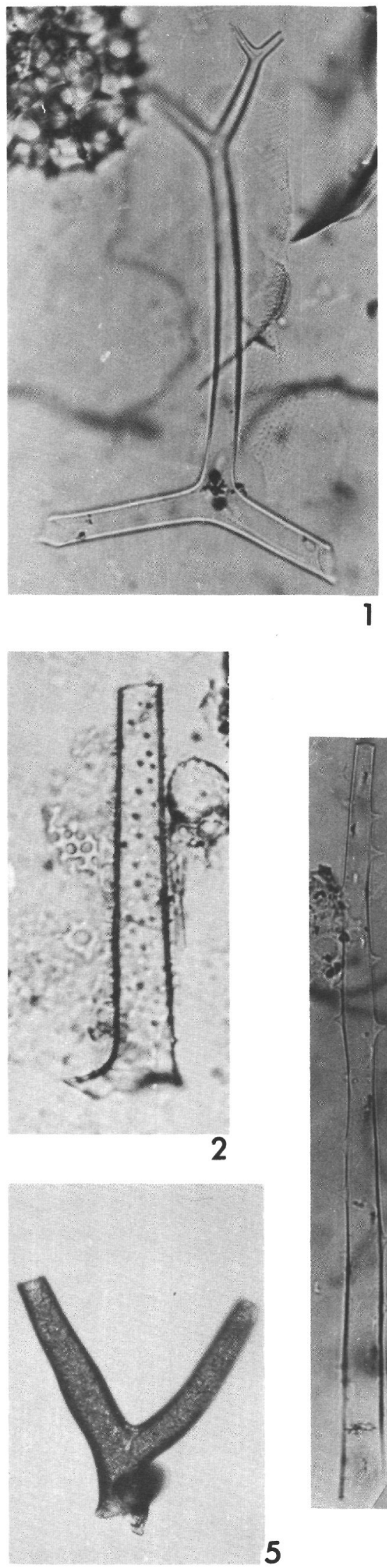

PLATE 3
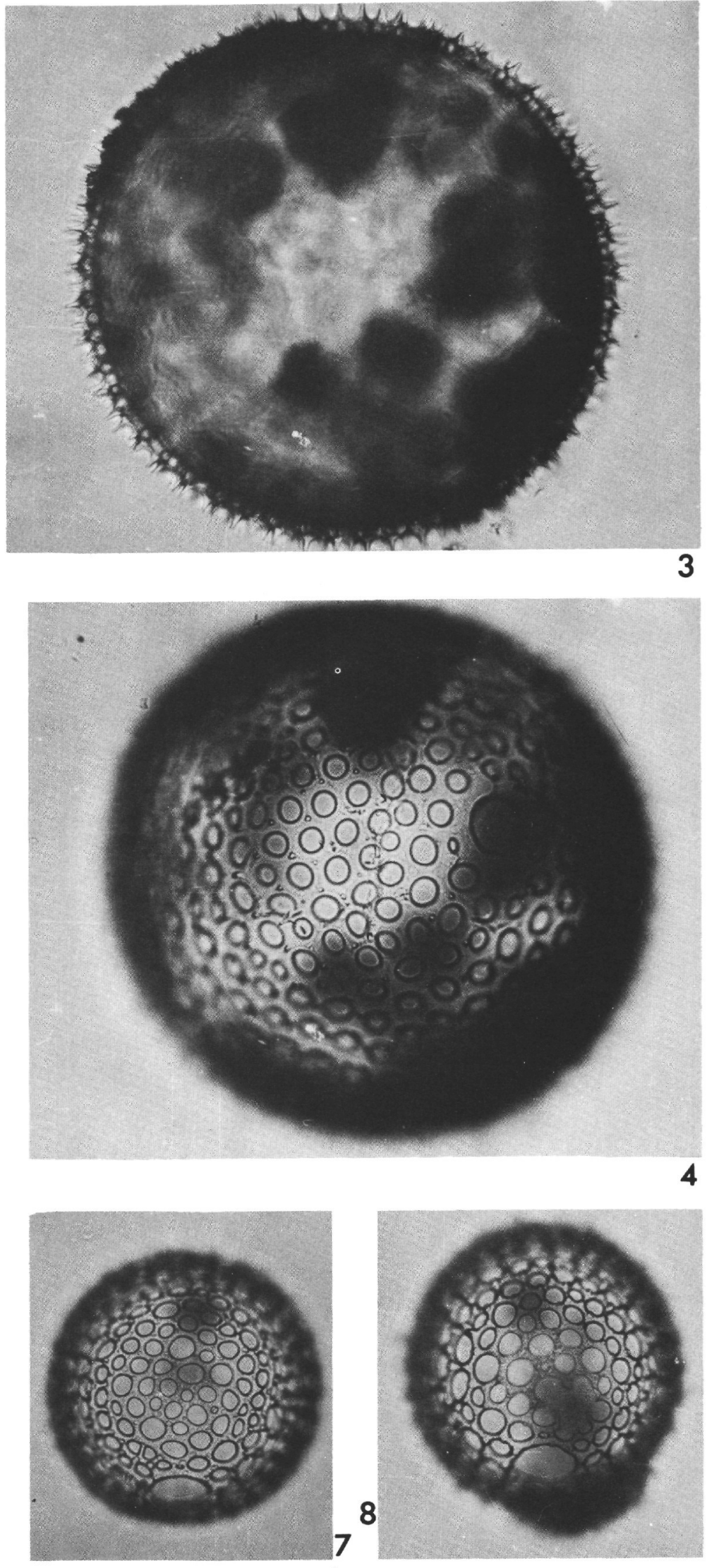
PLATE 4

All figures $\times 160$

Figures 1, 2, 5 Castanea ? sp., DSDP 203-1-2, 80-82 cm.

Figure 3 Castanidium moseleyi, fragment of shell, DSDP $205-6-1,80-82 \mathrm{~cm}$.

Figures 4, 6-8, Castanidium ? fenestratum, DSDP 203-1-2, 80-82 cm. 10,11

Figure 9 Castanidium sp., DSDP 203-1-2, 80-82 cm. 

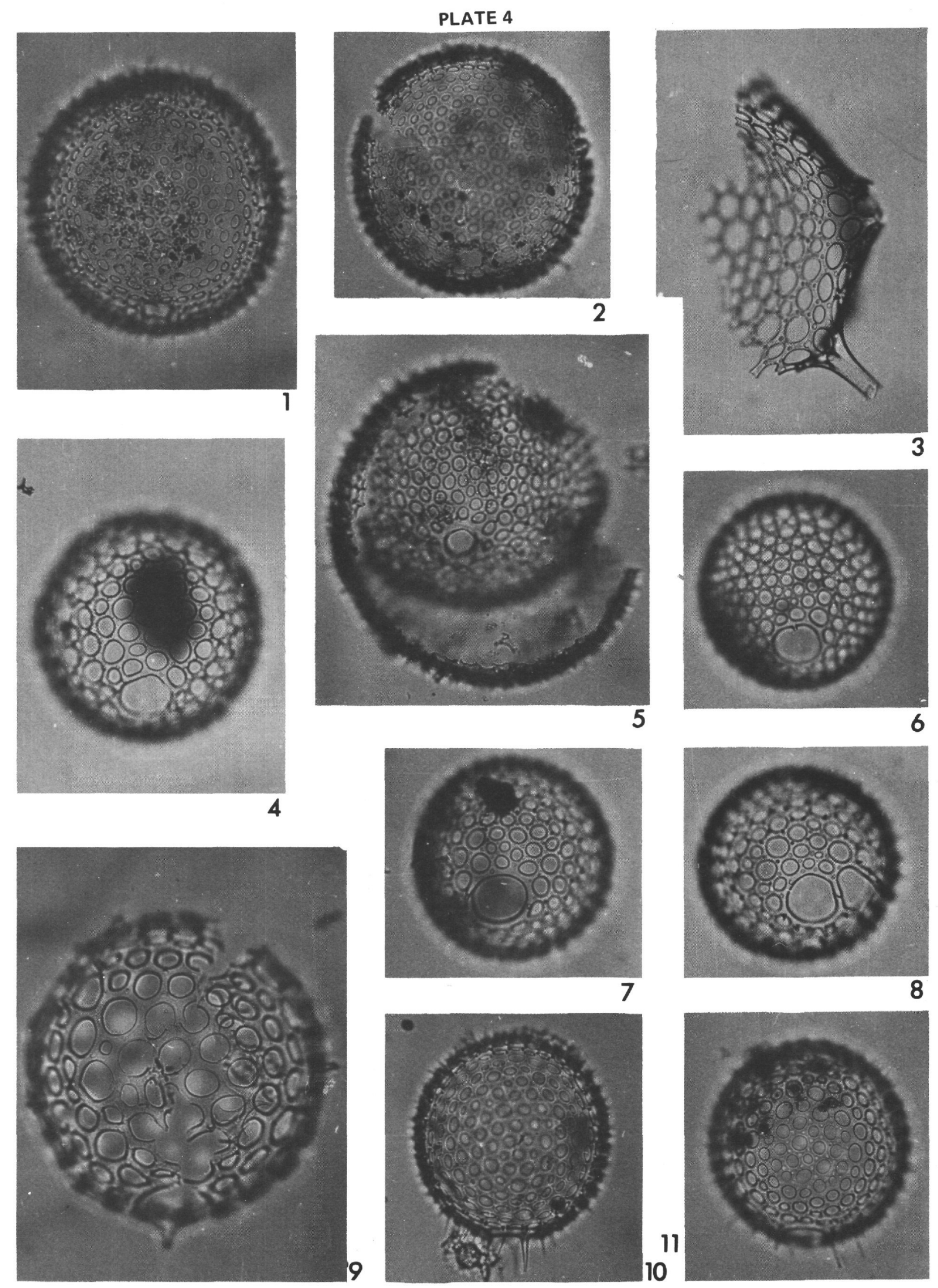


\section{PLATE 5}

Figures 1, 2, 8, X460; Figures 3-5, $\times 160$;

Figure 6, X1100; Figure 9, $\times 1500$

Figures 1, 2, 6 Porospathis holostoma, DSDP 203-2-1, 94-96 cm.

1,2: the same specimen focused on surface and on aboral end.

6: a detail of the superficial ornamentation.

Figures 3, 5 Castanidium ? fenestratum, DSDP 203-1-2, 80-82 cm.

Figure 4 Castanea ? sp. 1, DSDP 203-1-2, 80-82 cm.

Figures 7, 9, 10 Medusetta? costata, DSDP 205-6-1, 80-82 cm.

7, 10: the same specimen focused on surface and on diameter.

9: The same, portion of surface much magnified.

Figure 8 Euphysetta elegans, lateral view, DSDP 203-1-4, $80-82 \mathrm{~cm}$. 
Plate 5

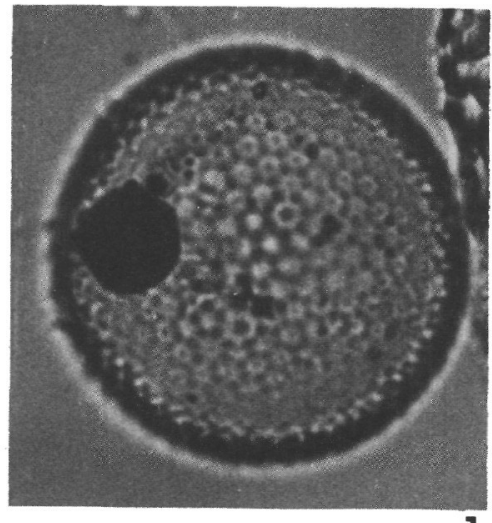

1
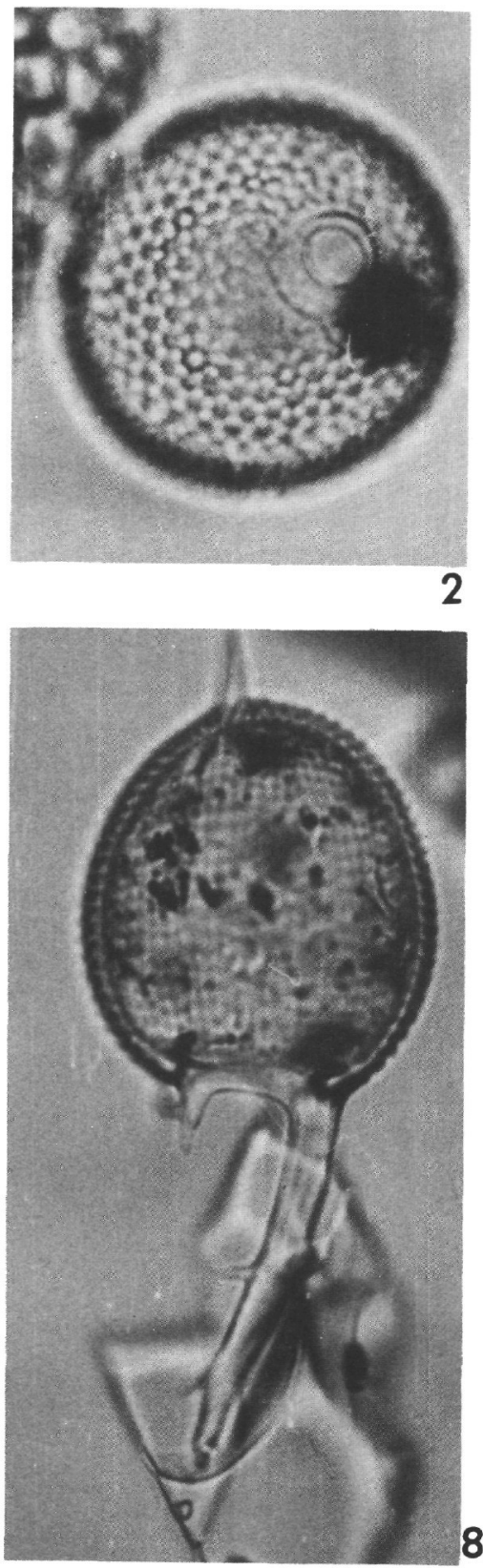
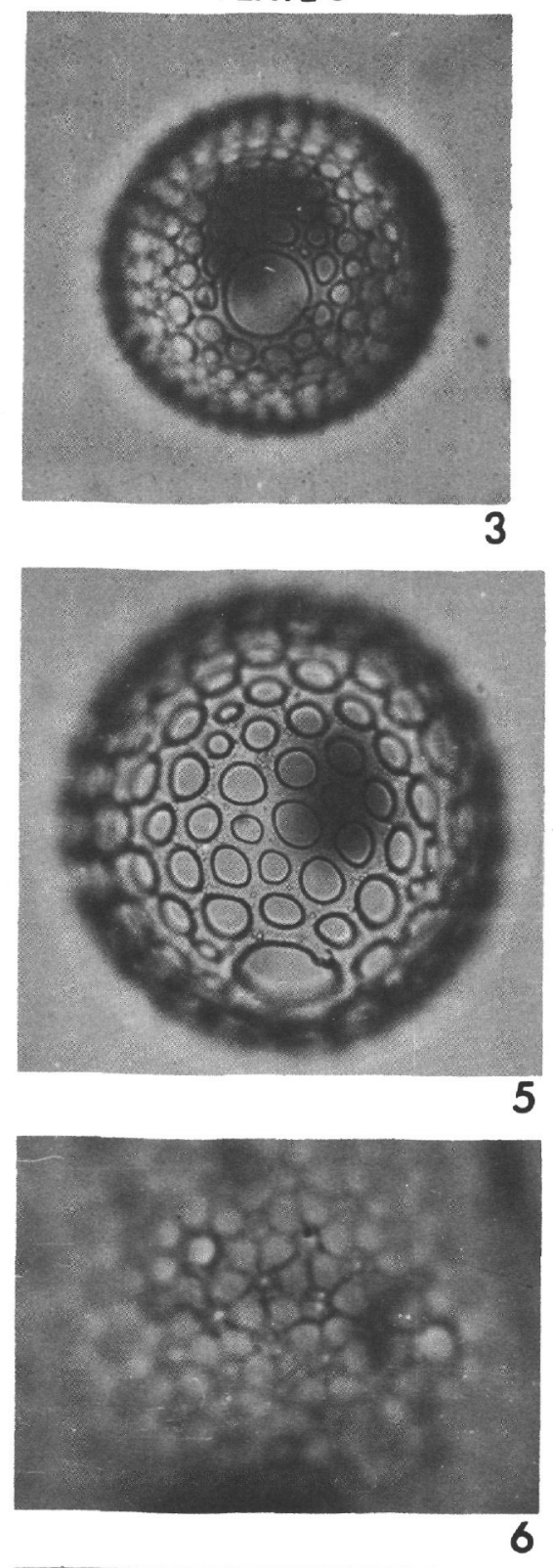

6

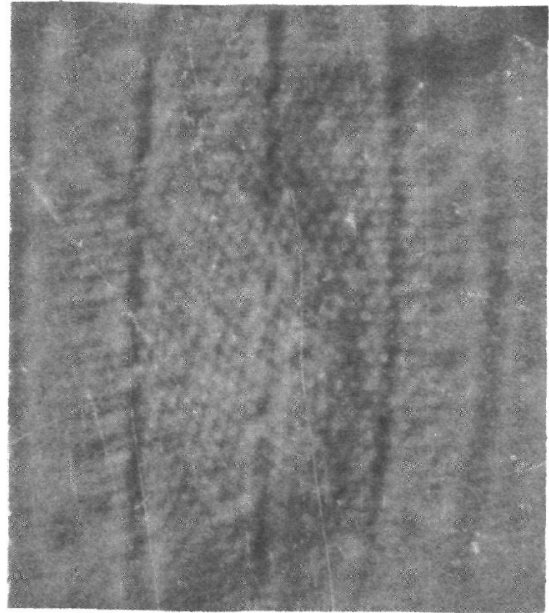

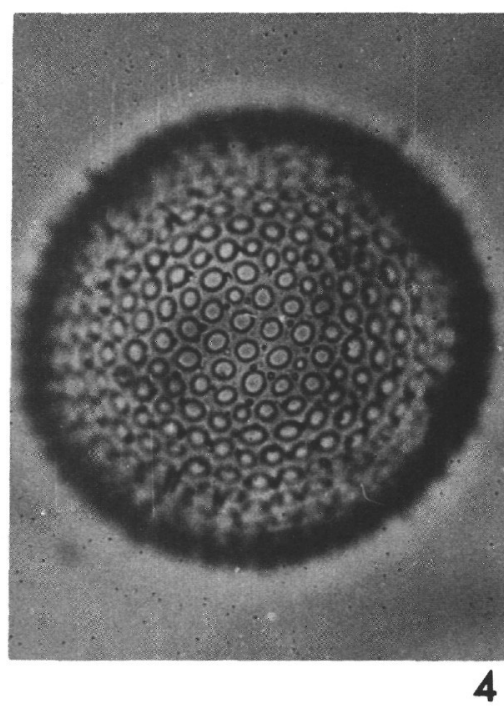

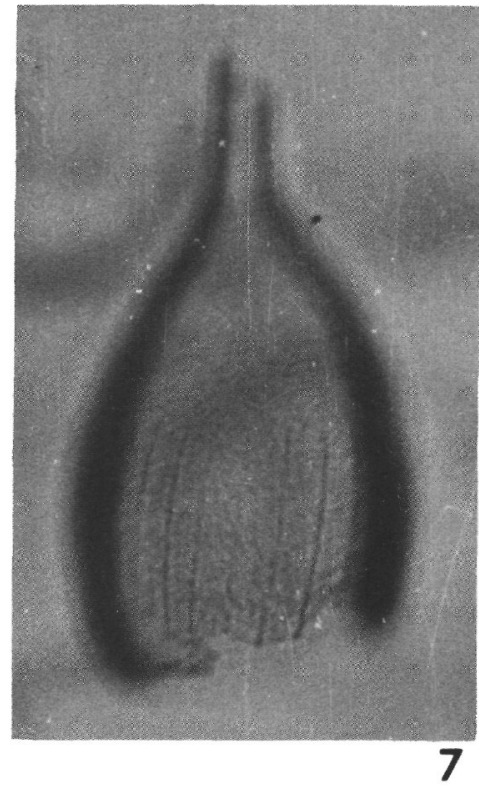

7

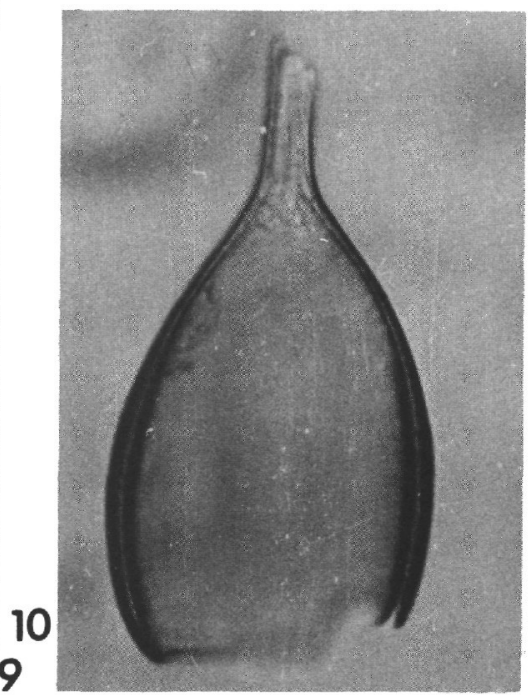


PLATE 6

Figures 1-5, 7, 8, X460; Figure 9, $\times 200$

\section{Figures.1-3 Euphysetta elegans}

1, 2: lateral view, DSDP 203-1-1, 81-83 cm.

3: ventral view, DSDP 203-2-1, 94-96 cm.

Figures 4, 5 Euphysetta sp., the same specimen focused at surface and at diameter, DSDP 205-6-1, 80-82 cm.

\section{Figures 6-8 Lirella marina}

6: Scanning electron micrograph showing details of surface ornamentation.

7, 8: DSDP 203-2-1, 94-96 cm.

Figure 9

Planktonetta ? sp., peristomal fragment, DSDP $203-1-1,81-83 \mathrm{~cm}$. 


\section{PLATE 6}
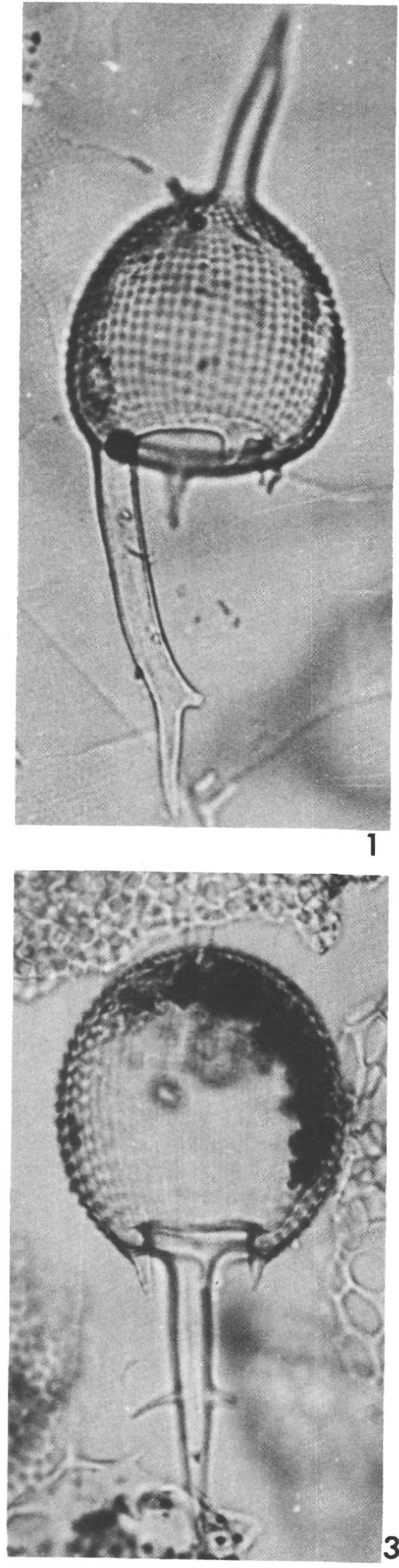
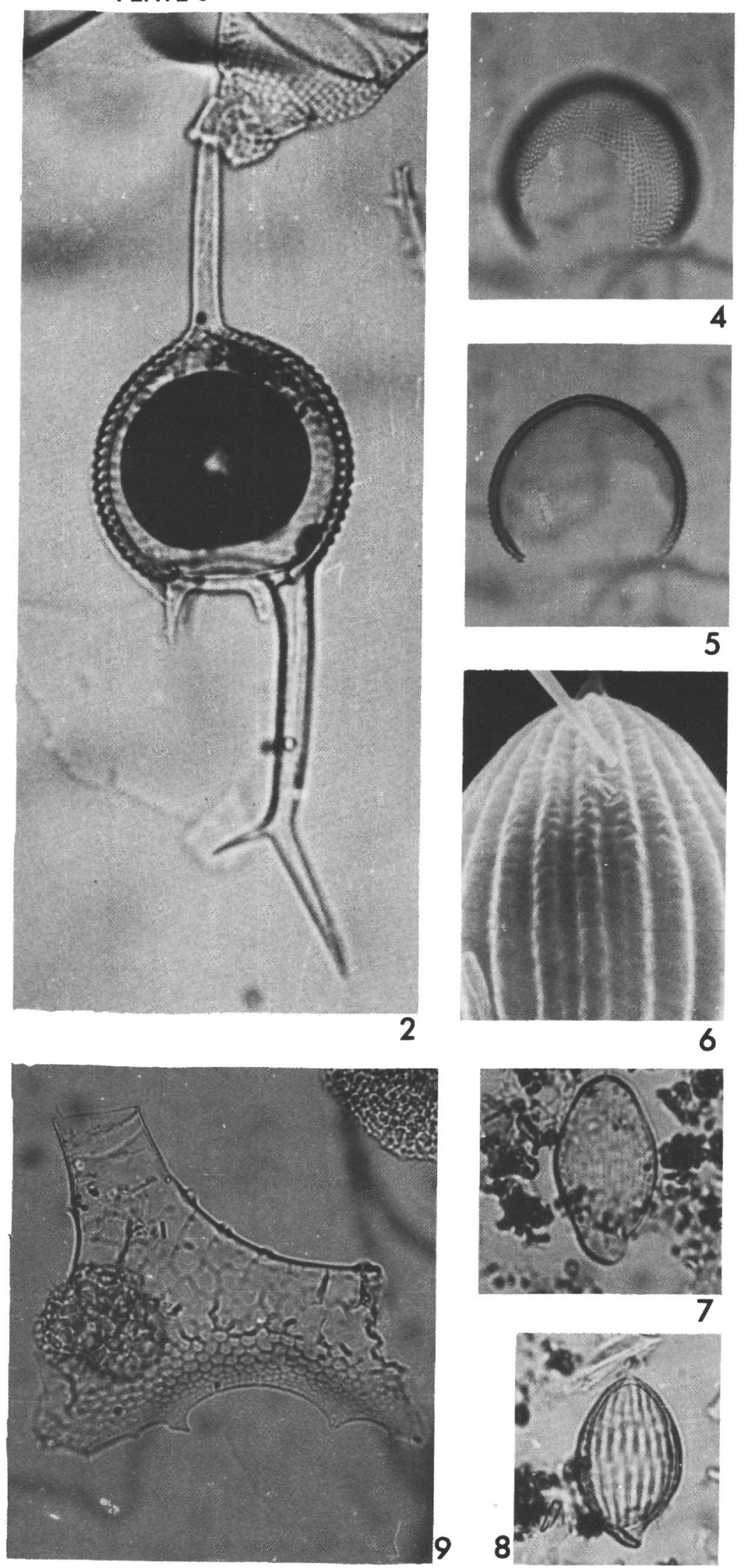


\section{PLATE 7}

All Figures $\times 520$

Figures 1,2 Lithogromia ? sp. 2 (? Protocystis thomsoni), DSDP 203-2-1, 94-96 cm.

1: In the central part is inserted a picture of the same specimen focused at surface.

Figures 3, $4 \quad$ Lirella melo

3: DSDP 206-13, CC

4: DSDP 203-2-1, 94-96 cm.

Figure 5

Lithogromia ? sp. 1 (? Protocystis xiphodon), lateral view, DSDP 203-1-4, 80-82 cm.

Figure 6 Protocystis cf. thomsoni, DSDP 203-2-1, 94-96 cm. 
PLATE 7
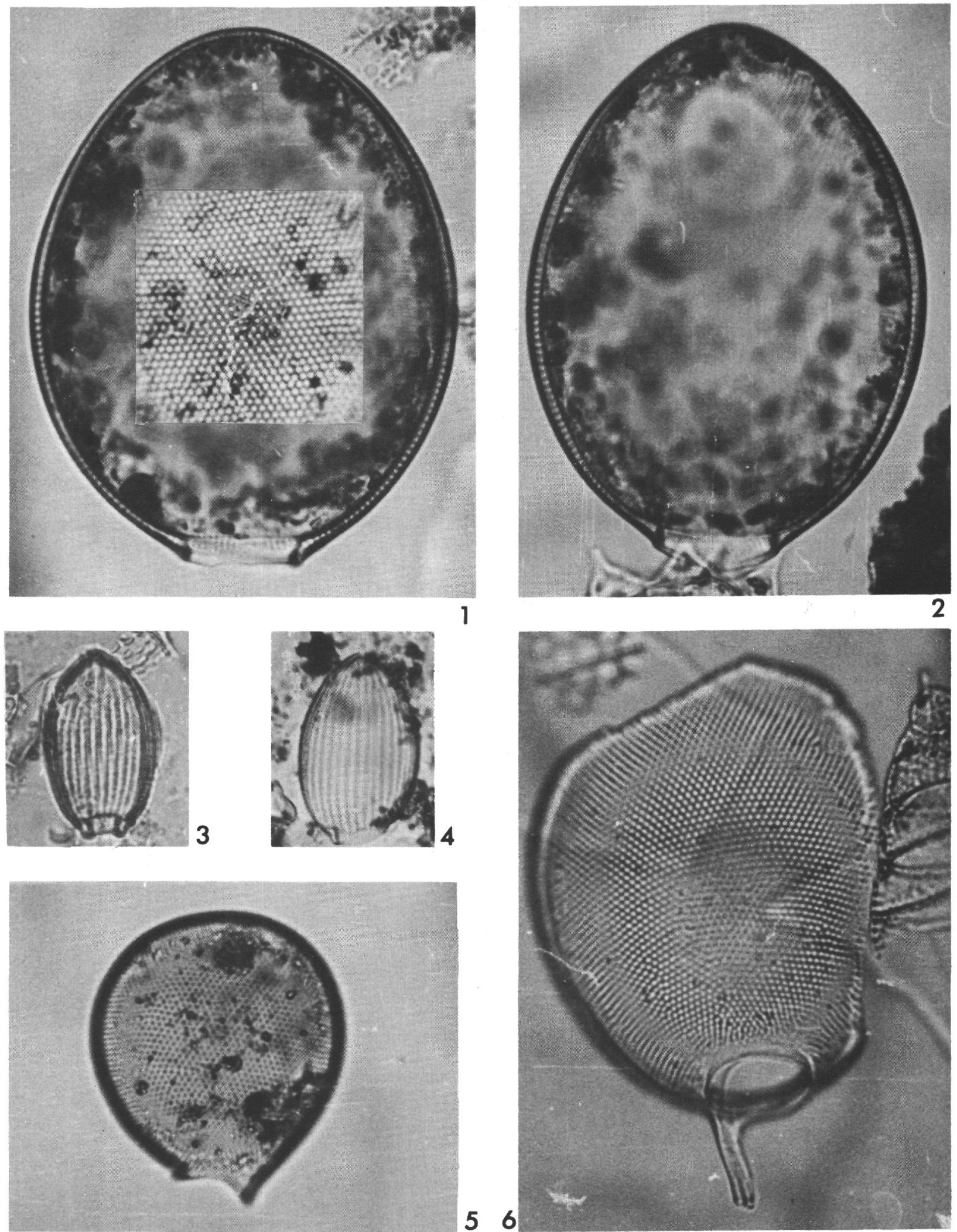


\section{PLATE 8}

Figures 1-5, X520; Figures 6-10, X980.

Figures 1-4 Lithogromia ? sp. 1 (? Protocystis xiphodon), DSDP 203-2-1, 94-96 cm.

$1,2,4$ : Lateral view.

3: Ventral view.

Figure 5 Protocystis harstoni, DSDP 203-2-1, 94-96 cm.

Figures 6-8 Borgertella caudata, right view showing the diaphragmatic tube, DSDP 206-8, CC.

7, 8: The same specimen focused at surface and at diameter.

Figures 9, $10 \quad$ Borgertella erectostoma

9: Left view, DSDP 205-6-5, 70-72 cm.

10: Right view, DSDP 205-7-3, 70-72 cm. 
PHAEODARIAN RADIOLARIA

PLATE 8
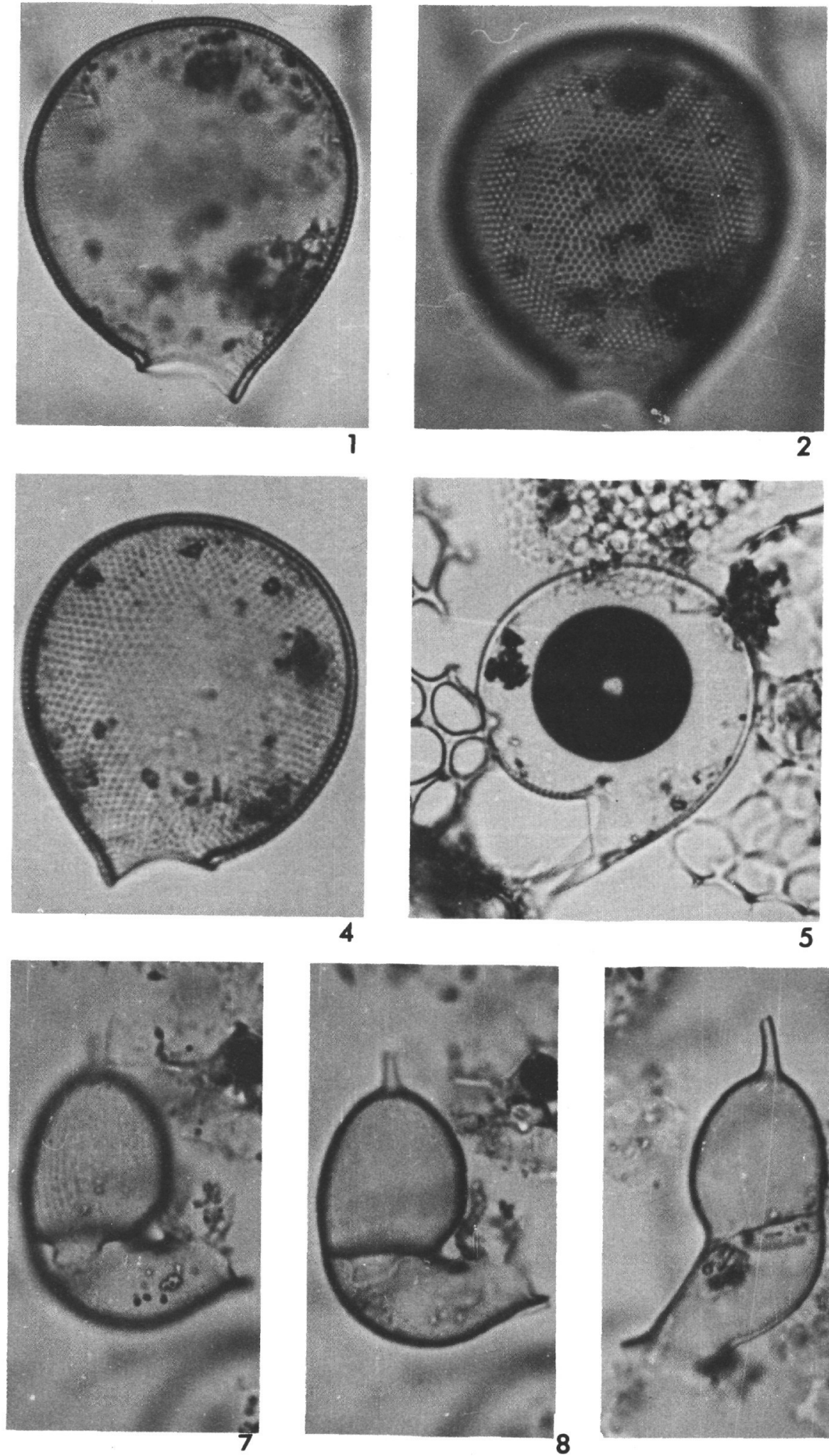
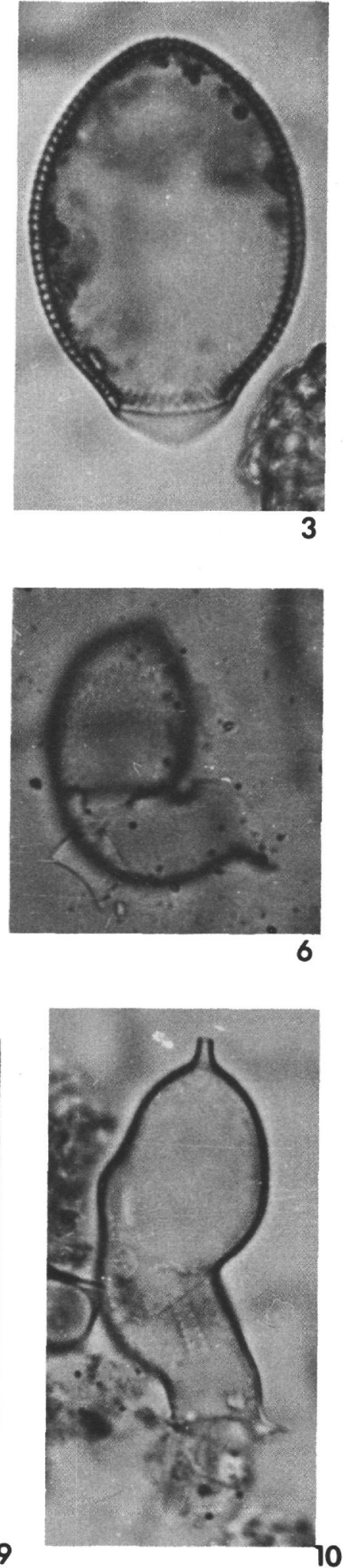


\section{PLATE 9}

Figures 1, 2, X740; Figures 3-8, X520.

Figure 1 Euphysetta lucani, DSDP 203-2-1, 94-96 cm.

Figure 2 Protocystis xiphodon, DSDP 203-2-1, 94-96 cm.

Figures 3-5 Atlanticella sp. 1, median fragments of spines, DSDP 206-20, CC.

3, 4: One specimen focused at surface and at center.

Figure 6 Euphysetta pusilla, DSDP 203-2-1, 94-96 cm.

Figure $7 \quad$ Euphysetta cf. nathorstii, DSDP 203-2-1, 94-96 cm.

Figure 8 Lirella marina, DSDP 203-2-1, 94-96 cm. 
PHAEODARIAN RADIOLARIA

PLATE 9
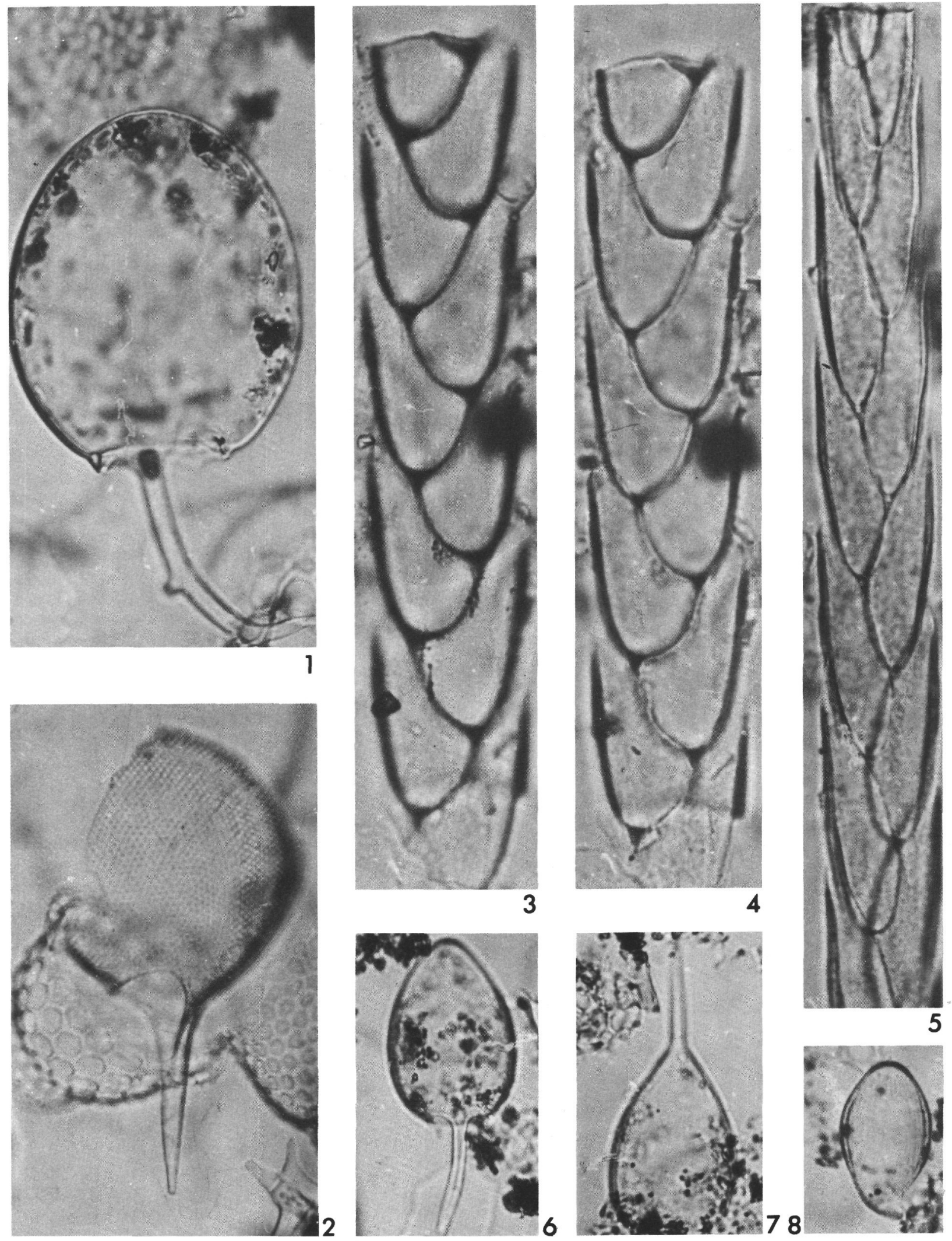


\section{PLATE 10}

Figures 1-8, X980; Figure 9, X1050.

Figures 1-5 Atlanticella sp. 1

1: Distal end of spine.

2-5: Median fragments of spines.

1, 2, 4, 5: DSDP 206-22, CC.

3: DSDP 206-20, CC.

Figures 6, $8 \quad$ Atlanticella sp. 2

6: DSDP 206-22, CC.

8: DSDP 206-13, CC.

Figure 7

Planktonetta? sp., DSDP 203-2-1, 94-96 cm.

Figure 9 Verticillate spine (tube), DSDP 205-5-1, 18-20 cm, illustrated also in Plate 11, Figure 10. 
Plate 10
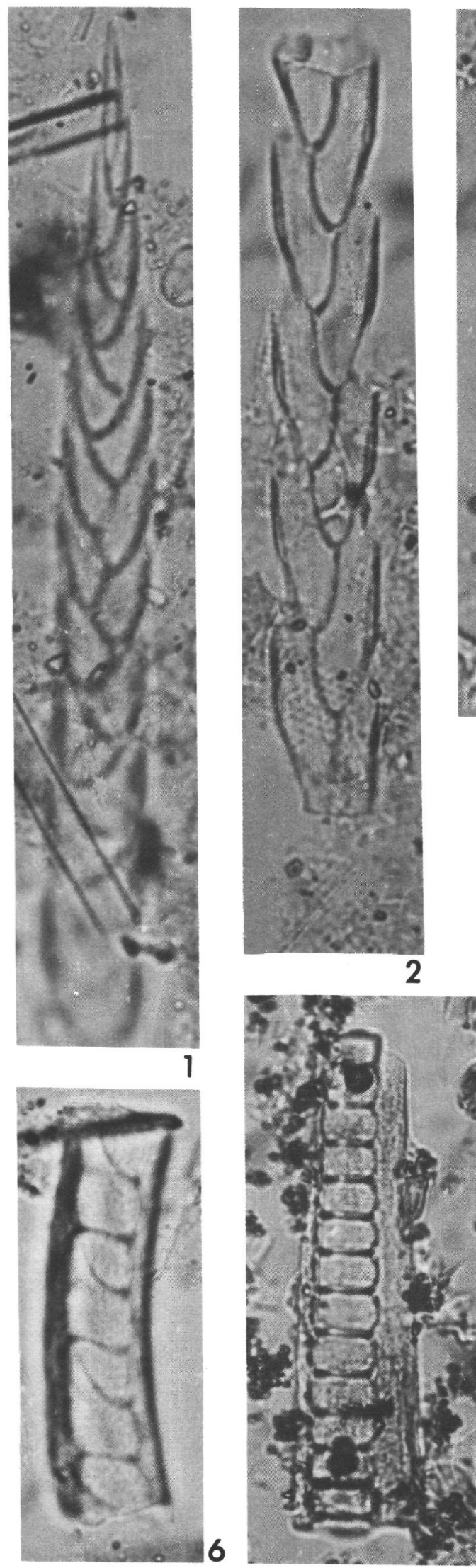

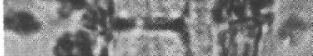

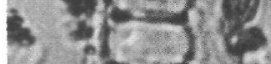

- $15=3$

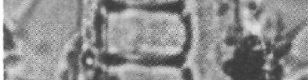

- $16=3 \log ^{2}$

-4)

ix

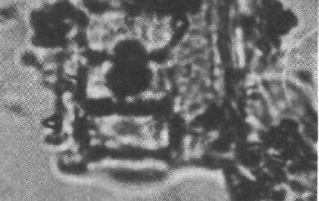

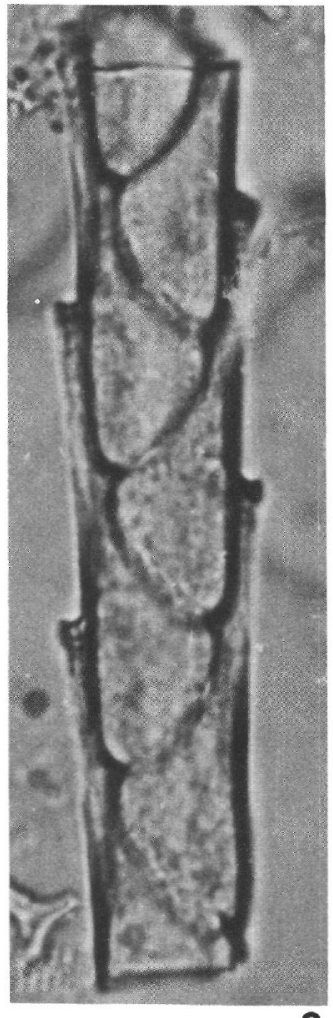

3
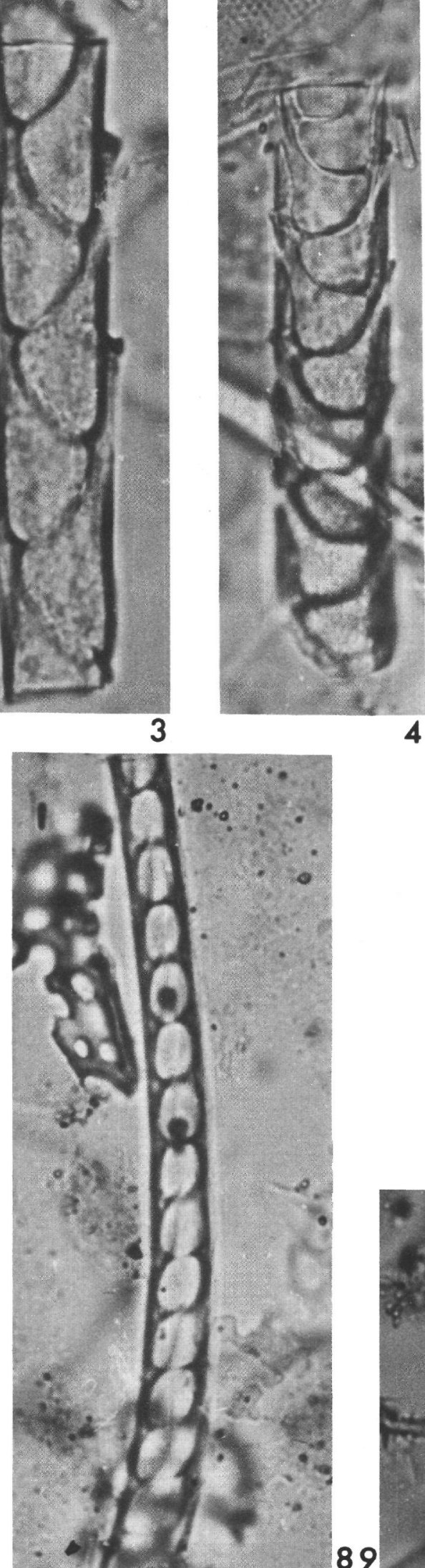

$x+\frac{1}{3}$
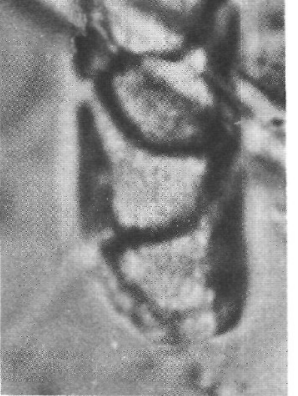

4

6.
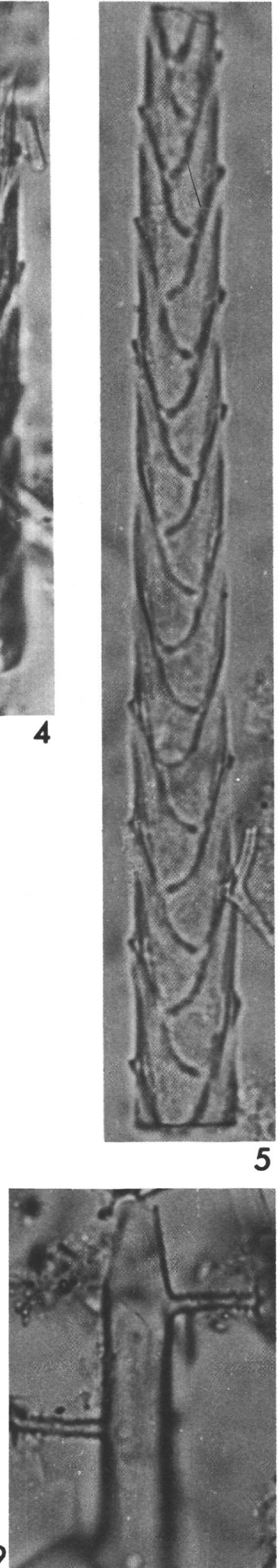


\section{PLATE 11}

Figures 1-9, X385; Figure 10, X530.

Figures 1,2 Aulographis taumorpha 1: DSDP 203-1-4, 80-82 cm.

2: DSDP 203-1-1, $81-83 \mathrm{~cm}$.

Figure 3 Aulographonium candelabrum, DSDP 203-2-1, 94-96 $\mathrm{cm}$.

Figures 4, 7 Coelodendrids, gen. et sp. indet. 4: DSDP 203-1-1, 81-83 cm. 7: DSDP 203-1-2, 80-82 cm.

Figures 5,9 Aulographonium cf. indicum 5: DSDP 203-2-1, 94-96 cm. 9: DSDP 205-6-1, 80-82 cm.

Figure 6 Aulacanthid ?, gen. et sp. indet., DSDP 206-19, CC.

Figure 8 Aulographonium pulvinatum, DSDP 203-1-2, 80-82 $\mathrm{cm}$.

Figure 10 Verticillate spine (tube), gen. et sp. indet., DSDP $205-5-1,18-20 \mathrm{~cm}$. 
PHAEODARIAN RADIOLARIA

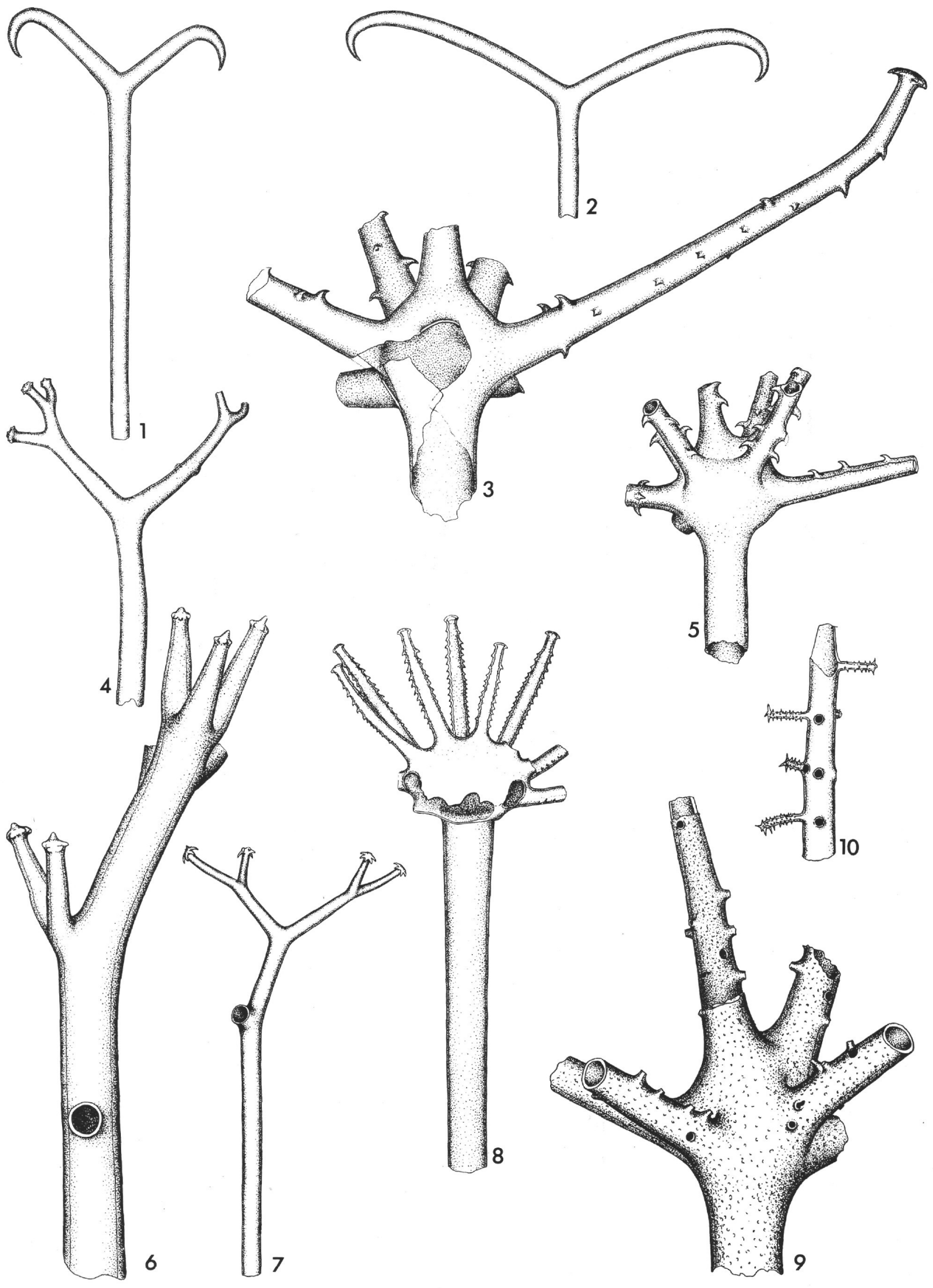




\section{PLATE 12}

Figures $14, \times 385$; Figures 5-21, $\times 530$

Figures 1, 2, 4 Coelodendrids, gen. et sp. indet.

1, 2: Proximal parts of radial spines, DSDP 206-29, CC.

4: Distal part of radial spine DSDP 203-1-1, 81-83.

Figure 3 Terminal spine of phaeodarian nature, DSDP 206-28, CC.

Figure $5 \quad$ Euphysetta pusilla, DSDP 203-2-1, 94-96 cm.

Figure 6 Euphysetta lucani, DSDP 203-2-1, 94-96 cm.

Figure 7 Euphysetta nathorstii, DSDP 203-2-1, 94-96 cm.

Figure 8 Euphysetta elegans, DSDP 203-1-1, 81-83 cm.

Figure $9 \quad$ Lirella melo, DSDP 204-1-1, 0-2 cm.

Figures 10-12 Lirella marina, lateral view

10, 11: DSDP 203-2-1, 94-96 cm.

12: DSDP 203-2-2, $45-47 \mathrm{~cm}$.

Figures 13-17 Borgertella caudata

13, 14, 16, 17: Right view showing the diaphragmatic tube slightly dorsalwards directed.

15: Dorsal view showing the diaphragmatic tube nearby the right side of the shell.

13: DSDP 206-8, CC.

$14,15,17$; DSDP 203-2-1, 94-96 cm.

16: DSDP 206-6, CC.

Figures 18-21 Borgertella erectostoma, Late Miocene.

18, 19, 21: Right view.

20: Left view.

18: The diaphragmatic tube is destroyed.

19-21: The diaphragmatic tube is long and dorsalwards directed.

18-20: DSDP 205-6-5, 70-72 cm.

21: DSDP 205-7-3, 70-72 cm. 
PHAEODARIAN RADIOLARIA

PLATE 12
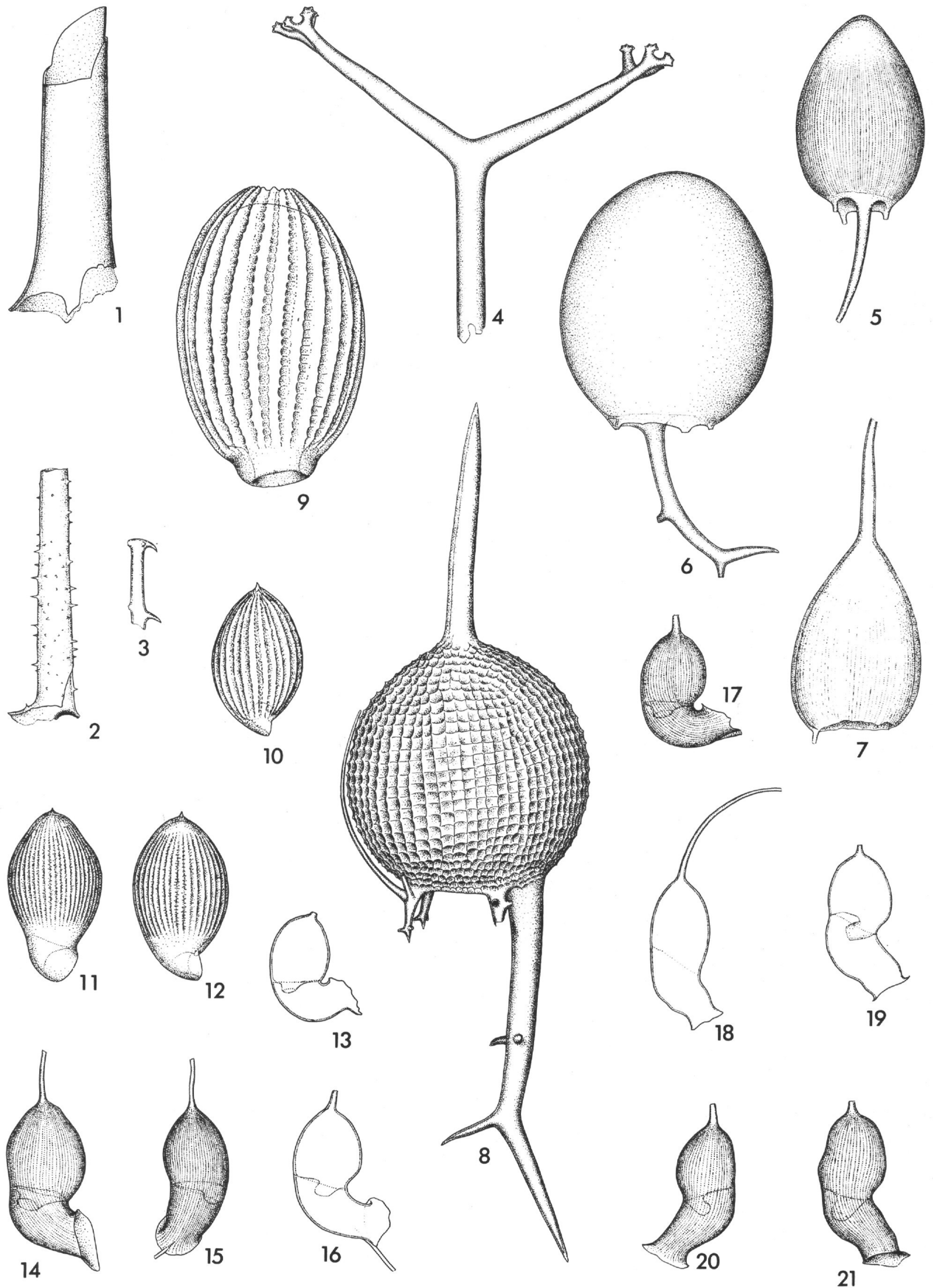


\section{PLATE 13}

Figures 1, 2, X385; Figures 4-10, X530;

Figures $11-13, \times 285$

Figure 1 Medusetta inflata, peristomal fragment, DSDP 203-1-1, 81-83.

Figures 2, 3 Medusetta ? costata, DSDP 205-6-1, 80-82 cm.

3: A portion of shell much magnified showing the pores between two longitudinal ridges.

Figures 4-6 Atlanticella sp. 2

4: DSDP 206-14, CC.

5: DSDP 206-13, CC.

6: DSDP 206-22, CC.

Figures 7, 9 Atlanticella sp. 1 DSDP 206-20, CC.

Figure 8 Planktonetta ? sp. DSDP 203-2-1, 94-96 cm.

Figures 10-13 Concharium binoculatum

10: Details of the alveolar structure showing pores in the walls separating alveoli, DSDP 206-20-2, 70-72 $\mathrm{cm}$.

11: a bivalved skeleton facing the smaller valve, DSDP 206-20-3, 70-72 cm.

12: Transversal section through a bivalved shell, DSDP 206-20-2, 70-72 cm.

13: Inner view of the larger valve, DSDP 206-20-1, $70-72 \mathrm{~cm}$. 


\section{PLATE 13}
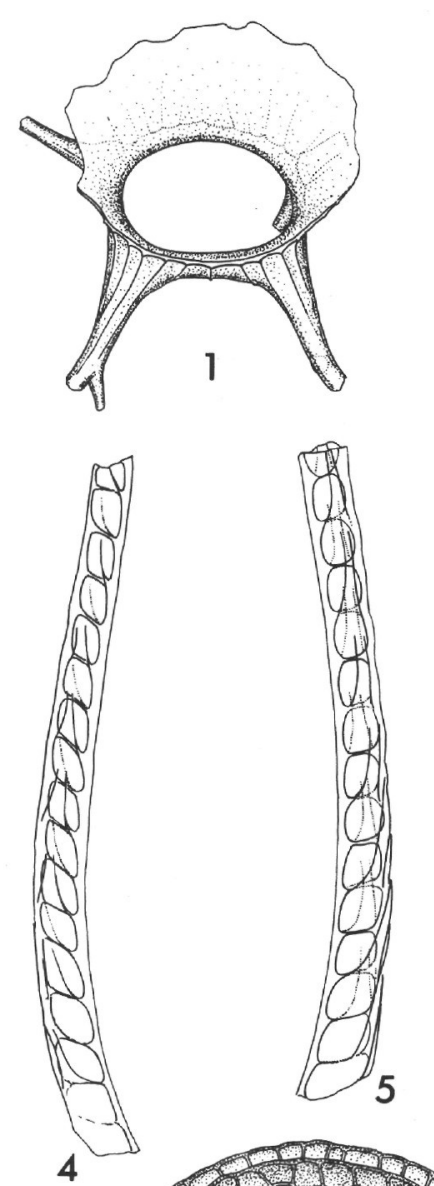
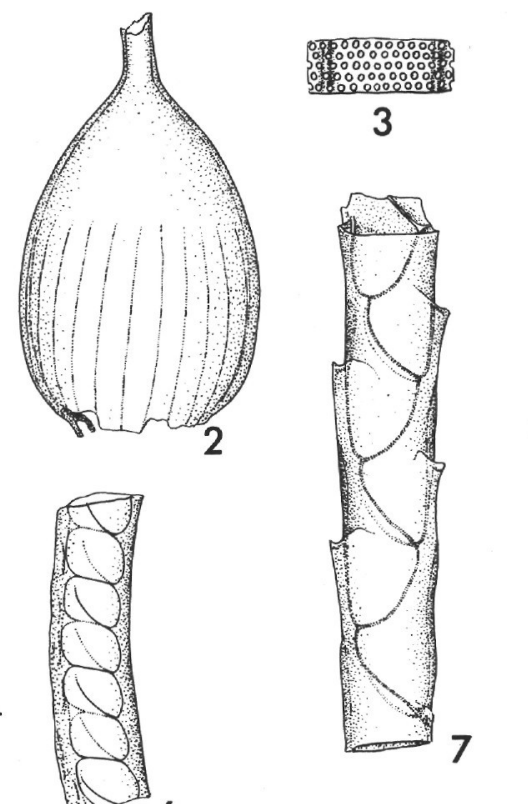
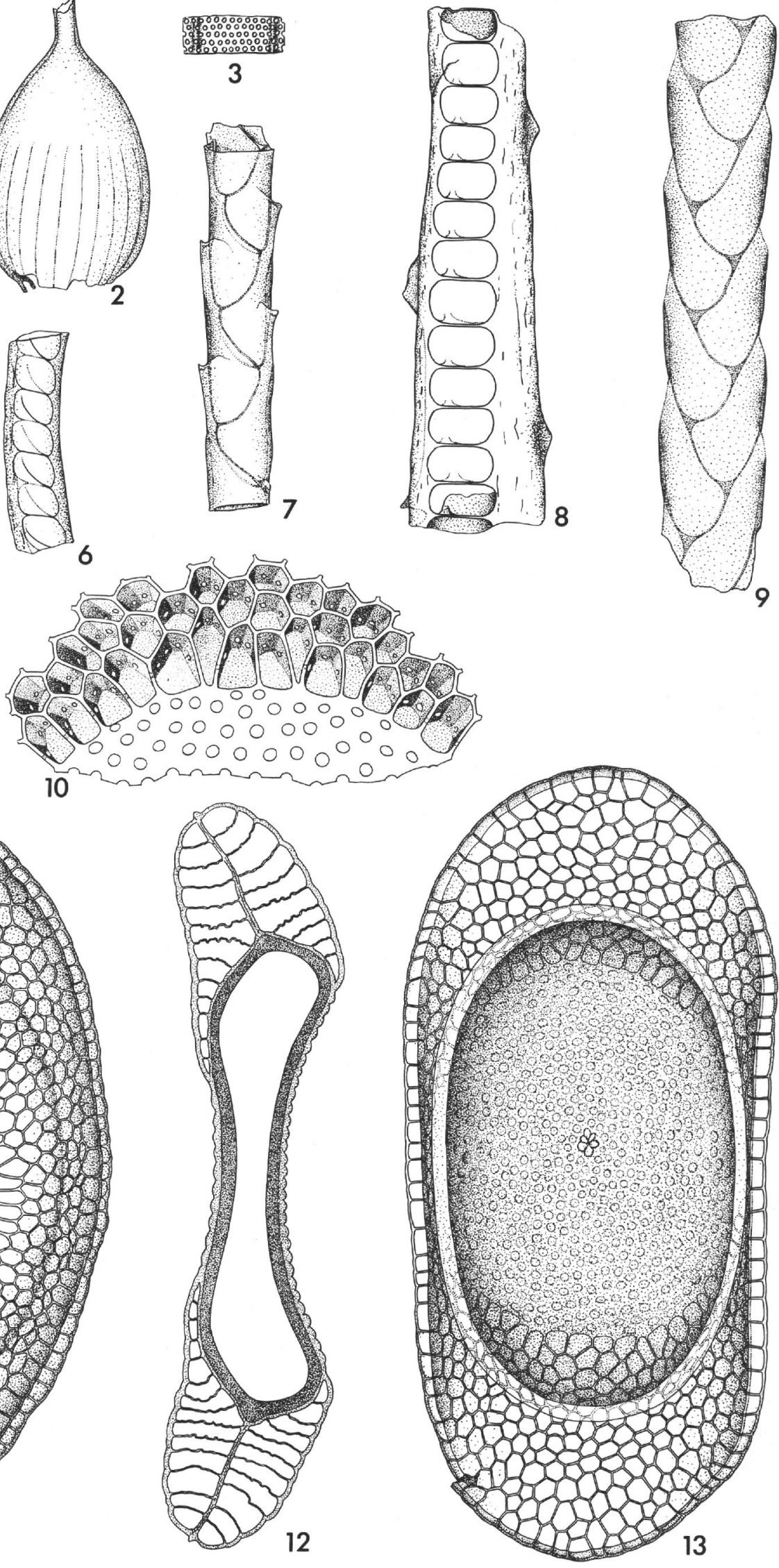